\title{
Rimski vojaki na območju Slovenije od ustanovitve Akvileje do vdora Markomanov in Kvadov
}

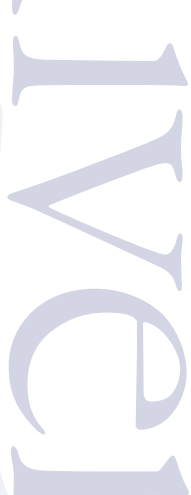

\author{
Jan Cotič
}

The presented paper is based on already published inscriptions mentioning roman soldiers, their functions and units in which they served. This type of research problem was chosen during the review of current state of research and literature about the Roman army in today's Slovenia. In addition to other (non-military) inscriptions, the majority of them are stored in lapidaries of the National museum of Slovenia in Ljubljana and in regional museums of Celje and Ptuj-Ormož. The remaining part of the inscriptions is distributed among the Dolenjska museum in Novo mesto, Bela krajina museum in Metli$\mathrm{ka}$ and in the lapidary of the Carinthian regional museum in Slovenj Gradec. Some inscriptions are also inbuilt in churches, castles, mills and houses.

Inscriptions with its content supplement the archeological findings of the discussed period and contribute to a better and more comprehensive picture of roman military presence and functioning in the region of today's Slovenia. Roman military inscriptions are collected in a catalog and accurately analyzed according to military functions and units mentioned on inscriptions. Its aim is to explain the presence and the structure of the roman army in present-day Slovenia between the foundation of Aquileia and the invasion of the Marcomanni and the Quadi. All Inscriptions after this period are therefore listed in tabular form only.

Key words: Roman period, epigraphic, roman provinces, roman army, military units, military functions

pregledom stanja raziskav in literarure je moč ugotoviti, da pomemben vir za sestavo celostne slike o rimski vojaški aktivnosti na slovenskem prostoru predstavljajo viri antičnih avtorjev, ${ }^{1}$ ki so s konkretnimi materialnimi dokazi podprti zgolj na posameznih lokacijah (npr. Grad pri Šmihelu, Dolge njive pri Vrhniki, Grad pri Reki, reka Ljubljanica, Ločica pri Polzeli itd.). Slovenski prostor je v času rim-

I Titus Livius - Aburbe Conditaliber XLI (Marjeta Šašel Kos, Situla Volume 43: Appian and Illyricum (Ljubljana: Narodni muzej Slovenije, 2005), 32 I-322), Appianos - Romaiká (Šašel Kos, Rimsko osvajan je zahodnega Balkana (Ljubljana: Zveza zgodovinskih društev Slovenije, 2010), 176), Hostius - Bellum Histricum (Šašel Kos, Appian and Illyricum, 323), Tacitus - Annales, Ab excessu divi Augusti, Cassius DioRhomaike historiae skih osvajalnih pohodov veljal za prostor $\mathrm{z}$ izrazito prehodno lego in stičišče med Italijo in jugovzhodno Evropo. Zato je bila nastanitev legij ali manjših vojaških oddelkov v veliki meri povezana z gradnjo cestnega omrežja, obrambo pred morebitnimi vdori obmejnih sovražnih ljudstev in bila kasneje pogojena $\mathrm{z}$ nadzorom rimskih trgovskih in transportnih poti, ki so vodile $\mathrm{v}$ matično Italijo.

Analiza obravnavanih vojaških napisov bo pokazala ali je bila prisotnost vojaških oddelkov na slovenskem prostoru pogojena $\mathrm{z}$ osvajanjem jugovzhodnoalpskega in zahodnobalkanskega prostora ter kako ohranjeni napisi odražajo razmerje v številu vojakov in vojaških oficirjev. 
Rimski vojaški napisi najdeni v Sloveniji so bili kot tema raziskave že podrobneje obravnavani predvsem za območje Emone in Celeje. Kot del raziskave povezane $\mathrm{z}$ nastankom Emone so nekatere vojaške napise obravnavali Balduin Saria, ${ }^{2}$ Jaroslav Šašel ${ }^{3}$ in Marjeta Šašel Kos, ${ }^{4}$ Julijana Visočnik pa je poglobljeno raziskavo vojaških napisov opravila za območje Celeje in njenega agra, zato so njene ugotovitve samo povzete. Vojaški napisi iz Emone, Petovione, Nevioduna in Pretorija Latobikov so bili kot celota zabeleženi in opisani $\mathrm{v}$ strokovnih in znanstvenih objavah, npr. vodnikih po lapidarijih ${ }^{6}$ pristojnih muzejev, katalogih razstav ter $\mathrm{v}$ znanstvenih objavah.?

Rezultati raziskovanja so predstavljeni kvantitativno v obliki tabel ter kvalitativno. Slovenski prostor je bil v smislu vojaškega delovanja v veliki meri prehodnega značaja, zato je moč sklepati, da bodo opazna minimalna odstopanja $\mathrm{v}$ razmerju med napisi vojakov in vojaških oficirjev. Preučeni rezultati so dali drugačen pogled na obravnavano temo, saj je raziskava pokazala, da je razmerje predstavnikov vojske in oficirjev odvisno od kraja (in njegovega statusa ter časa nastanka), kjer so bili nastanjeni.

\section{Katalog vojaških napisov}

Iz Emone in njene okolice je poznanih dvanajst vojaških napisov: deset nagrobnih napisov (št. I, 2, 5, 6, 7, 8, 9, IO, II in I2/I3) in dva votivna oltarja (št. 3 in 4$)$. Na štirih spomenikih so izpričani štirje veterani, pri tem sta $v$ treh primerih eno-

2 Balduin Saria, "Vojaški nagrobni napis iz Emone," Kronikaslovenskih mest 3, no. I (1937): 46-48.

3 Jaroslav Šašel, Situla, Volume 3 o - Opera Selecta: Pro Legato (Ljubljana: Narodni muzej, 1992), 305-315.

$4 \quad$ Marjeta Šašel Kos, "Je bila Emona nekdanji tabor 15. legije in veteranska kolonija?" Zgodovinski časopis 52, no. 3 (112) (1998): 317-329, Marjeta Šašel Kos, "The isth Legion at Emona - Some thoughts," Zeitschrift für Papyrologie und Epigrafik I09 (1995): 227-244.

5 Julijana Visočnik, "Vojaški napisi iz Celeje in njene okolice," Arheoloskivestnik 59 (2008): 325-357.

6 BlagojJevremov, Vodnik po lapidarju I. del (Ptuj: Pokrajinski muzej, 1988), Marjeta Šašel Kos, Lapidarij Narodnega muzeja Sloveni je-Rimskispomeniki-Vodnik (Ljubljana: Narodni muzej Slovenije, 2004).

7 Lovenjak, Situla, Volume 37: Neviodunum - Inscriptiones Latinae Slovenia (ILSI) I, Šašel Kos, "Je bila Emona nekdanji tabor I5. legije in veteranska kolonija?", 317-329. ti navedeni (št. 9, II in I2/13) in v enem ne (št. IO). Starost je navedena na nagrobniku veterana Tita Varia (št. 9), ki je ob svoji smrti štel 60 let.

Tabela I: Število obravnavanih rimskih vojaških napisov najdenih v Sloveniji

\begin{tabular}{lc} 
Emona & 13 \\
\hline Petovio & 20 \\
\hline Neviodunum & 16 \\
\hline Practorium Latobicorum & 18 \\
Celeia & 52 \\
$\begin{array}{l}\text { predstavniki vojske na posamičnih lokacijah po Slo- } \\
\text { veniji }\end{array}$ & 1
\end{tabular}

SKUPAJ 120

Z oznako, ki se nanaša na navadnega vojaka (miles), so izpričani trije vojaki (št. 5, 6 in 7). Izraz miles se pojavi tudi na nagrobnikih pretorijanca Pudensa (št. 2) in Lucija Elija Nigrina (št. 8), ki je kot vojak marinec (militi classis) služil v Panonskem ladjevju. Kot edini omenjeni pretorijanec je Pudens vojaško službo opravljal v Drugi pretorijanski kohorti (Cohors II Praetoriae), a je očitno ni dokončal, saj je na nagrobniku navedeno, da je odslužil 7 let in umrl pri 25. letih.

$\mathrm{Na}$ devetih napisih je navedena pripadnost vojakov posameznim legijam. Petnajsta Apolonova legija je navedena na napisih št. 4, 5, 9 in I2, trinajsta Dvojna legija pa na napisih št. 3, 6, 7 , in II. $\mathrm{Na}$ nagrobnem napisu veterana Lukija Oklacija (št. 12) je omenjen tudi veteran Tit Kalvencij, ki je vojaško službo opravljal v osmi Avgustovi legiji (št. 13). Slednja je bolje dokumentirana na območju današnjega Ptuja. Imena legij so na napisih št. 4, 9, I2, I3 navedena samo s številko, kar dokazuje, da so nekatere legije bile prisotne na tem območju že pred uvedbo Avgustovih vojaških reform.

Med vojaškimi napisi iz Emone je po opravljanju vojaške službe najbolj izpoveden nagrobnik Tita Junija Montana (št. 1), ki navaja, da je svojo bogato vojaško kariero šestkrat opravljal kot vojaški tribun, šestkrat je bil prefekt konjenice,

Kate Gilliver, "The Augustan Reform and Structure of the Imperial Army," in A Companion to the Roman Army, ur. Paul Erdkamp (Chichester: Willy-Blackwell, 2007), 185, 188. 
Tabela 2: Predstavniki vojaških oficirjev v Emoni

\begin{tabular}{|c|c|c|c|c|c|c|c|}
\hline$\check{S}_{\mathrm{t}}$ & Ime oficirja & $\begin{array}{c}\text { Funkcija, } \\
\text { vojaška enota }\end{array}$ & Starost & Datacija & Vrsta napisa & Najdišče & Objava \\
\hline I. & $\begin{array}{l}\text { Titus Iunius } \\
\text { Montanus }\end{array}$ & $\begin{array}{l}\text { tribunus mili- } \\
\text { tium, praefec- } \\
\text { tus equitum, } \\
\text { praefectus fab- } \\
\text { rum, pro le- }\end{array}$ & / & $\begin{array}{l}\text { avgustejsko ob- } \\
\text { dobje }\end{array}$ & nagrobni napis & Ljubljana & $\begin{array}{l}\text { Šašel Kos, } \\
2004,85, \text { št. } 36\end{array}$ \\
\hline
\end{tabular}

Tabela 3: Predstavniki vojske v Emoni

\begin{tabular}{|c|c|c|c|c|c|c|c|}
\hline$\check{S}_{\mathrm{t}}$. & Ime vojaka & $\begin{array}{c}\text { Funkcija, } \\
\text { vojaška enota }\end{array}$ & Starost & Datacija & Vrsta napisa & Najdišče & Objava \\
\hline \multirow{3}{*}{2.} & & Praetoriani & & & & & \\
\hline & Pudens & $\begin{array}{l}\text { miles cohortis } \\
\text { II praetoriaie }\end{array}$ & 25 & verjetno i. st. & nagrobni napis & Ljubljana & $\begin{array}{l}\text { Šašel Kos, } \\
2004,85 \text {, št. } 37\end{array}$ \\
\hline & & Signiferi & & & & & \\
\hline 3. & $\begin{array}{l}\text {... Valerius } A \\
\text { milianus }\end{array}$ & $\begin{array}{l}\text { signifer legi- } \\
\text { onis XIII Ge- } \\
\text { minae }\end{array}$ & / & verjetno 3. st. & $\begin{array}{l}\text { votivni napis } \\
\text { (posvetilo Jupi- } \\
\text { tru Odvračal- } \\
\text { cu zla ali Doli- } \\
\text { henskemu) }\end{array}$ & Ljubljana & $\begin{array}{l}\text { Šašel Kos, } \\
2004,82 \text {, št. } 17\end{array}$ \\
\hline & & Frumentarii & & & & & \\
\hline \multirow[t]{2}{*}{4.} & Vibius & $\begin{array}{l}\text { frumentarius } \\
\text { legionis XV }\end{array}$ & / & $\begin{array}{l}\text { prva polovi- } \\
\text { ca i. st. }\end{array}$ & $\begin{array}{l}\text { votivni napis } \\
\text { (oltar posvečen } \\
\text { Cereri) }\end{array}$ & Ljubljana & $\begin{array}{l}\text { Šašel Kos, } \\
2004,8 \circ \text {, št. } 8\end{array}$ \\
\hline & 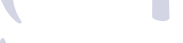 & Milites & & & & & \\
\hline 5. & $\begin{array}{l}\text { Caius Clodius } \\
\text { Secundus }\end{array}$ & $\begin{array}{l}\text { miles legio- } \\
\text { nis XV Apoli- } \\
\text { naris }\end{array}$ & / & $\begin{array}{l}\text { prva polovi- } \\
\text { ca i. st. }\end{array}$ & nagrobni napis & Ljubljana & $\begin{array}{l}\text { Šašel Kos, } \\
2004,86 \text {, št. } 38\end{array}$ \\
\hline 6. & $\begin{array}{l}\text { Marcus Aure- } \\
\text { lius Crispini- } \\
\text { anus }\end{array}$ & $\begin{array}{l}\text { miles legionis } \\
\text { XIII Geminae }\end{array}$ & / & $253-268$ & nagrobni napis & Ljubljana & $\begin{array}{l}\text { Šašel Kos, } \\
2004,87, \text { št. 4I }\end{array}$ \\
\hline 7. & / & $\begin{array}{l}\text { miles legionis } \\
\text { XIII Geminae }\end{array}$ & / & 3. st. & nagrobni napis & Ljubljana & $\begin{array}{l}\text { Šašel Kos, } \\
2004,87, \text { št. } 42\end{array}$ \\
\hline \multirow[t]{2}{*}{8.} & $\begin{array}{l}\text { Lucius Aelius } \\
\text { Nigrinus }\end{array}$ & $\begin{array}{l}\text { militi classis } \\
\text { Pannonicae }\end{array}$ & / & konec 2. ali 3. st. & $\begin{array}{l}\text { nagrobni napis } \\
\text { (odlomek nag- } \\
\text { robnika) }\end{array}$ & Ljubljana & $\begin{array}{l}\text { Šašel Kos, } \\
2004,87 \text {, št. } 44\end{array}$ \\
\hline & & Veterani & & & & & \\
\hline 9. & Titus Varius & $\begin{array}{l}\text { veteranus legi- } \\
\text { onis XV }\end{array}$ & 60 & $\begin{array}{l}\text { prva polovi- } \\
\text { ca i. st. }\end{array}$ & nagrobni napis & Ljubljana & $\begin{array}{l}\text { Šašel Kos, } \\
2004,86, \text { št. } 39\end{array}$ \\
\hline IO. & $\begin{array}{l}\text { Caius } \\
\text { Vettennius }\end{array}$ & veteranus & / & $\begin{array}{l}\text { verjetno prva } \\
\text { polovica I. st. }\end{array}$ & nagrobni napis & Ljubljana & $\begin{array}{l}\text { Šašel Kos, } \\
2004,87 \text {, št. } 40 .\end{array}$ \\
\hline
\end{tabular}




\begin{tabular}{|c|c|c|c|c|c|c|c|}
\hline$\check{S}$ t. & Ime vojaka & $\begin{array}{c}\text { Funkcija, } \\
\text { vojaška enota }\end{array}$ & Starost & Datacija & Vrsta napisa & Najdišče & Objava \\
\hline II. & $\begin{array}{l}\text { Aurelius Io- } \\
\text { vinus }\end{array}$ & $\begin{array}{l}\text { veteranus legi- } \\
\text { onis XIII Ge- } \\
\text { minae }\end{array}$ & / & 3. st. & nagrobni napis & Ljubljana & $\begin{array}{l}\text { Šašel Kos, } \\
2004,87 \text {, št. } 43\end{array}$ \\
\hline 12. & $\begin{array}{l}\text { Lucius Ocla- } \\
\text { tius }\end{array}$ & $\begin{array}{l}\text { veteranus legi- } \\
\text { onis } \mathrm{XV}\end{array}$ & / & \multirow{2}{*}{$\begin{array}{l}\text { prva polovi- } \\
\text { ca I. st. }\end{array}$} & \multirow{2}{*}{ nagrobni napis } & \multirow{2}{*}{ Ljubljana } & \multirow{2}{*}{$\begin{array}{l}\text { Šašel Kos, } 1998 \text {, } \\
332, \text { št. } 3\end{array}$} \\
\hline 13. & $\begin{array}{l}\text { Titus Calven- } \\
\text { tinus }\end{array}$ & $\begin{array}{l}\text { veteranus legi- } \\
\text { onis VIII }\end{array}$ & / & & & & \\
\hline
\end{tabular}

Tabela 4: Predstavniki vojske v Petovioni

\begin{tabular}{|c|c|c|c|c|c|c|c|}
\hline Št. & Ime vojaka & $\begin{array}{c}\text { Funkcija, } \\
\text { vojaška enota }\end{array}$ & Starost & Datacija & Vrsta napisa & Najdišče & Objava \\
\hline & & Beneficiarii & & & & & \\
\hline \multirow[t]{2}{*}{14.} & $\begin{array}{l}\text { Caius Corne- } \\
\text { lius Proculus }\end{array}$ & $\begin{array}{l}\text { beneficiarius } \\
\text { tribunus, miles } \\
\text { legionis XIII } \\
\text { Geminae }\end{array}$ & / & sredina I. st. & nagrobni napis & $\begin{array}{l}\text { Spodnja Haj- } \\
\text { dina }\end{array}$ & $\begin{array}{l}\text { Jevremov, } 1988 \text {, } \\
46, \text { št. I } 4\end{array}$ \\
\hline & & Centuriones & & & & & \\
\hline 15. & $\begin{array}{l}\text { Marcus Petro- } \\
\text { nius Classicus }\end{array}$ & $\begin{array}{l}\text { centurio legi- } \\
\text { onis VIII Au- } \\
\text { gusta }\end{array}$ & / & $\begin{array}{l}\text { prva polovi- } \\
\text { ca I. st. }\end{array}$ & nagrobni napis & $\begin{array}{l}\text { Ptuj (videmska } \\
\text { cerkev) }\end{array}$ & $\begin{array}{l}\text { Jevremov, } 1988 \text {, } \\
39 \text {, št. } 6\end{array}$ \\
\hline 16. & $\begin{array}{l}\text { Marcus Clau- } \\
\text { dius Avitus }\end{array}$ & $\begin{array}{l}\text { centurio legio- } \\
\text { nis X Geminae } \\
\text { pia fidelis }\end{array}$ & / & 2. st. & $\begin{array}{l}\text { votivni napis } \\
\text { (oltar posvečen } \\
\text { Jupitru) }\end{array}$ & Vičava & $\begin{array}{l}\text { Jevremov, } 1988, \\
99, \text { št. } 105\end{array}$ \\
\hline \multirow[t]{2}{*}{17.} & Martial & $\begin{array}{l}\text { centurio legi- } \\
\text { onis XIII Ge- } \\
\text { minae }\end{array}$ & / & 3. st. & $\begin{array}{l}\text { votivni napis } \\
\text { (oltar posvečen } \\
\text { Diani) }\end{array}$ & Ptuj (Titovtrg) & $\begin{array}{l}\text { Jevremov, I988, } \\
\text { I09, št. I20 }\end{array}$ \\
\hline & & Praefecti & & & & & \\
\hline 18. & $\begin{array}{l}\text { Aelius Ma- } \\
\text { rinus }\end{array}$ & $\begin{array}{l}\text { praefectus co- } \\
\text { hortis II Hispa- } \\
\text { norum }\end{array}$ & / & \multirow{2}{*}{$\begin{array}{l}\text { druga polovi- } \\
\text { ca 2. in začetek } \\
\text { 3. st. }\end{array}$} & \multirow{2}{*}{ nagrobni napis } & \multirow{2}{*}{ Vičava } & \multirow{2}{*}{$\begin{array}{l}\text { Jevremov, } 1988 \text {, } \\
\text { II } 5 \text {, št. I32 }\end{array}$} \\
\hline \multirow[t]{2}{*}{19.} & $\begin{array}{l}\text { Publius Aelius } \\
\text { Marcianus }\end{array}$ & $\begin{array}{l}\text { preaefectus co- } \\
\text { hortis I Ger- } \\
\text { manorum }\end{array}$ & / & & & & \\
\hline & & Optii & & & & & \\
\hline \multirow[t]{2}{*}{20.} & $\begin{array}{l}\text { Lucius Faninus } \\
\text { Quadratus }\end{array}$ & $\begin{array}{l}\text { optio legionis } \\
\text { I Adiutricis pia } \\
\text { fidelis }\end{array}$ & / & 2. st. & nagrobni napis & $\begin{array}{l}\text { Ptuj (minorit- } \\
\text { ska cerkev) }\end{array}$ & $\begin{array}{l}\text { Jevremov, } 1988 \text {, } \\
37 \text { št. } 3\end{array}$ \\
\hline & & Primi hastati & & & & & \\
\hline 21. & Saturninus & $\begin{array}{l}\text { primus hasta- } \\
\text { tus legionis } \\
\text { VIII Augusta }\end{array}$ & 70 & $\begin{array}{l}\text { prva polovi- } \\
\text { ca i. st. }\end{array}$ & nagrobni napis & $\begin{array}{l}\text { Ptuj (videmska } \\
\text { cerkev) }\end{array}$ & $\begin{array}{l}\text { Jevremov, 1988, } \\
40, \text { št. } 7\end{array}$ \\
\hline
\end{tabular}




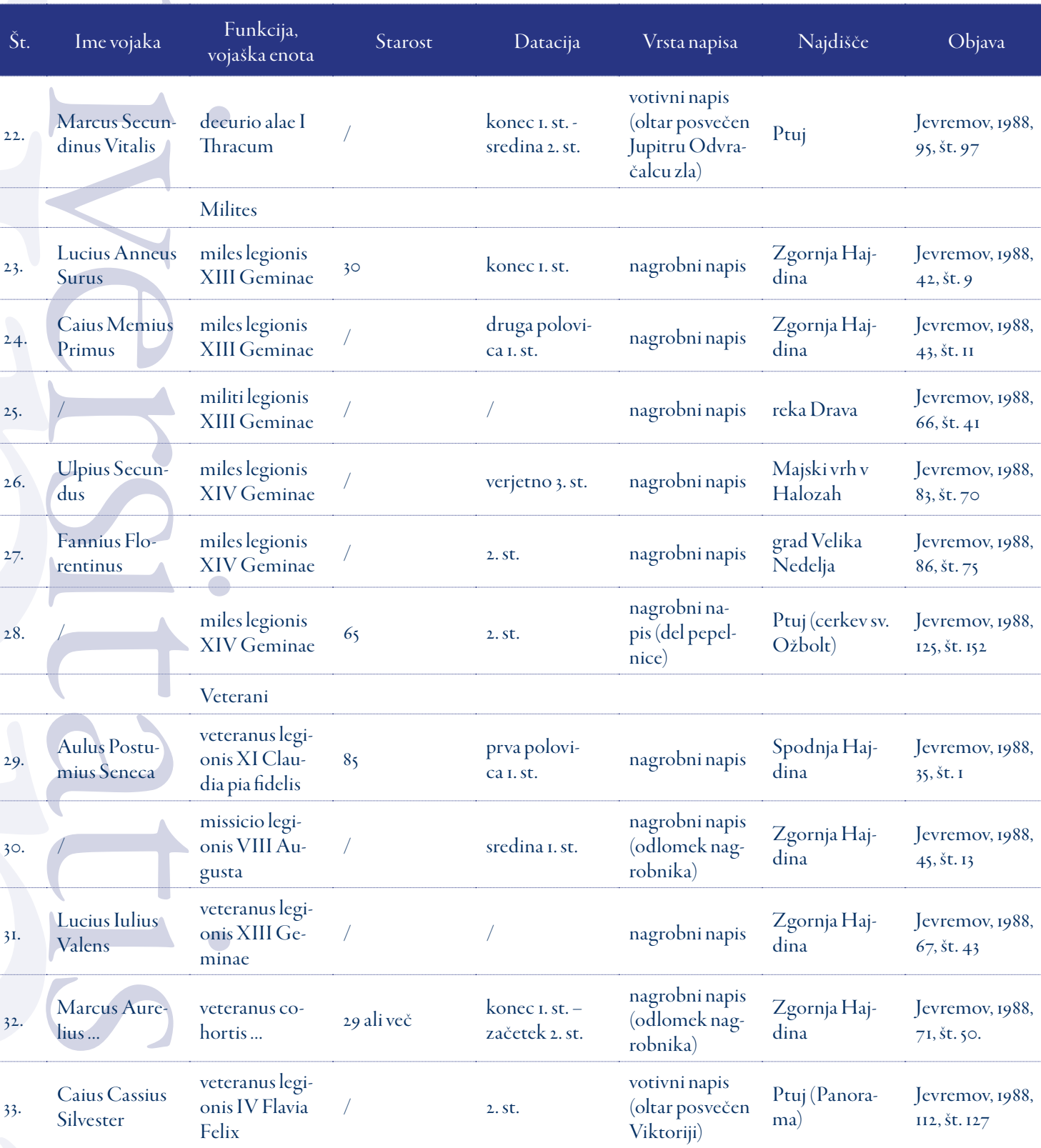

dvakrat načelnik inženirjev in dvakrat oficir viteškega stanu. ${ }^{9}$ Funkcija pro legato je nekoč bila interpretirana kot namestnik legijskega poveljnika, tako piše tudi Balduin Saria, ki je domneval, da je Montan poveljeval petnajsti Apolonovi legiji. ${ }^{10}$ Njegovo tezo je prvi ovrgel Jaroslav

9 Šašel Kos, Lapidarij Narodnega muzeja Slovenije-RimskispomenikiVodnik, 85, no. 36.

Io Saria, "Vojaški nagrobni napis iz Emone," 46.
Šašel, ki je natančno analiziral to funkcijo in zaključil, da ta naziv ni pomenil legijskega poveljnika, temveč oficirja viteškega stanu. ${ }^{I I}$ Ta naj bi opravljal različne vojaške, tehnične, predvsem pa administrativne funkcije $\mathrm{z}$ nalogo, da bi utrdil rimsko oblast na območjih, ki so bila šele ne-

I I Jaroslav Šašel, Situla, Volume 30 - Opera Selecta: Zur Frühgeschichte der XV. Legion und zur Nordostgrenze der Cisalpina zur Zeit Caesars (Ljubljana: Narodni muzej), 469-477. 
davno osvojena in priključena cesarstvu. ${ }^{12}$ Kasnejše študije in raziskave so dodatno potrdile, da zaključki Sarie niso pravilni, saj jim nasprotuje epigrafsko, numizmatično in arheološko gradivo. ${ }^{13}$ Med vojaškimi napisi iz Emone sta po funkciji omenjena tudi intendant petnajste Apolonove legije (št. 4) in zastavonoša ali nosilec znaka (signifer) trinajste Dvojne legije (št. 3).

Iz Petovione in njene okolice je znanih devetnajst vojaških napisov: trinajst nagrobnih napisov (št. I4, 15, I8/19, 20, 21, 23, 24, 25, 27, 28, 29, 31 in 32), štirje oltarji (št. $16,17,22$ in 33) in dva spomenika za katera ni mogoče natančno določiti vrste (št. 26 in 29).

$\mathrm{Na}$ petih spomenikih so izpričani veterani, pri tem so v štirih primerih (št. 29, 30, 31 in 33) enote navedene in $\mathrm{v}$ enem ne (št. 32). Veterani so na štirih napisih izpričani z oznako veteranus (št. $29,31,32$ in 33), medtem ko oznaka missicio nepoznanega vojaka (št. 30) izpričuje status odsluženega vojaškega roka. Starost vojakov je možno razbrati na petih napisih (št. 29, 21, 23, I 4 in 28). Zaokrožena je na 5 ali io let: 85 (št. 29), 70 (št. 26), 30 (št. I4) in 65 (št. 28) let, medtem ko nagrobnik Marka Avrelija (ime je nepopolno) navaja II let službovanja v neznani kohorti, iz česar lahko sklepamo, da je vojak imel vsaj 29 let, ko je preminil. ${ }^{\mathrm{It}} \mathrm{Na}$ nagrobniku je navedeno, da je bil veteran. Iz tega lahko sklepamo, da je bil vojak starejši in je bil II let pred smrtjo najverjetneje premeščen $\mathrm{v}$ drugo enoto. $\mathrm{Z}$ oznako miles je izpričanih pet vojakov (št. 23, 24, 25, 26 in 27), prav tako se pojavi še na nagrobniku tribunskega beneficiarija Kaja Kornelija Prokula (št. I4).

Pripadnost vojakov posameznim enotam je navedena na osemnajstih napisih. Osma Avgustova legija je izpričana na treh napisih (št. I5, 2I in 30), trinajsta Dvojna legija pa na šestih napisih (št. 23, 24, I 4, 25, 31 in I7), štirinajsta Gemina na treh (št. 26, 27 in 28), deseta Gemina (št. 16),

I2 Marjeta Šašel Kos, "Colonia Iulia Emona - the genesis of the Roman city," Arheološki vestnik 63 (2012), 100.

I3 Mitja Gaspari, »Apudhorridas gentis ...«začetki rimskega mesta Colonia Iulia Emona = beginnings of the Roman town of Colonia Iulia Emona (Ljubljana: muzej in galerije mesta Ljubljane, 2010), I 13 ; Šašel Kos, "Colonia Iulia Emona - the genesis of the Roman city," Iоo.

I4 Jevremov, Vodnik po lapidarju I. del, 71, no. 50. četrta Flavija Srečna (št. 33), enajsta Klavdijeva (št. 29) in prva Pomožna (št. 20) pa po enkrat. Med vojaškimi enotami je omenjen še desetnik konjeniškega oddelka prve Traške ale (decurio alae I Thracum) (št. 22). Na sarkofagu postavljenem $\mathrm{v}$ spomin preminulima staršema iz Vičave (št. I8), je navedeno, da sta naročnika sinova, ki sta vojaško službo opravljala kot načelnika oziroma polkovnika pomožnih enot: prva Germanska (Cohors I Germanorum) in druga Hispanska kohorta (Cohors II Hispanorum).

Iz Drnovega pri Krškem, kjer se je nekoč razprostiral rimski municipij Neviodunum, je vse rimske napise neviodunskega agra zbral in ovrednotil M. Lovenjak, ${ }^{15}$ vojaški napisi pa še niso bili strnjeno dokumentirani ali obravnavani. Dvanajst tovrstnih napisov je bilo najdenih $\mathrm{v}$ neposredni bližini antičnega mesta. Največ jih je iz Velikih Malenc ( 5 napisov) in Krške vasi ( 3 napisi) ter po en primer iz Leskovca pri Krškem, Valične vasi, Čateža in Dobove.

Po številu največ beneficiarskih napisov, ki jih sestavlja devet votivnih oltarjev (št. 35, 36, 37, $38,39,40,41,42$ in 43 ) in nagrobni napis (št. 44) konzularjevega beneficiarija iz obdobja druge polovice 2. in prve polovice 3. st.

Napisi št. 35, 40, 4I in 42 so bili najdeni na hribu Gradišče pri Velikih Malencah, kjer se je od 2. st. dalje nahajal poznorimski utrjeni kastel, ki je branil in nadzoroval rimsko cesto še $\mathrm{v}$ 6. st. ${ }^{16} \mathrm{Na}$ treh napisih sta poleg funkcije konzularjevega beneficiarija omenjeni tudi legiji v katerih so beneficiariji službovali. Na napisih št. 35 in 40 je navedena deseta Dvojna legija, na napisu št. 4I pa štirinajsta Dvojna legija $\mathrm{z}$ vzdevkom Martia victrix (Marsova zmagovita) (št. 4I). Med predstavniki vojske sta iz napisov omenjena Publij Maksimij Matern, ki je kot merilec desete Dvojne legije verjetno sodeloval pri postavljanju vojaških taborov svoje legije, in Maksimij Mansuet, ki je svojo službo opravljal kot centurion dvanajste Bliskovite legije. Mansuet je na-

I5 Lovenjak, Situla, Volume 37: Neviodunum - Inscriptiones Latinae Slovenia (ILSl) I, I4I-142.

Iva Mikl Curk, Slavko Ciglenečki and Davorin Vuga, Po poteh rimskih vojakov v Sloveniji (Ljubljana: Zavod Republike Slovenije za varstvo naravne in kulturne dediščine Slovenije, 1993), 193. 
Tabela s: Predstavniki vojske v Neviodunu

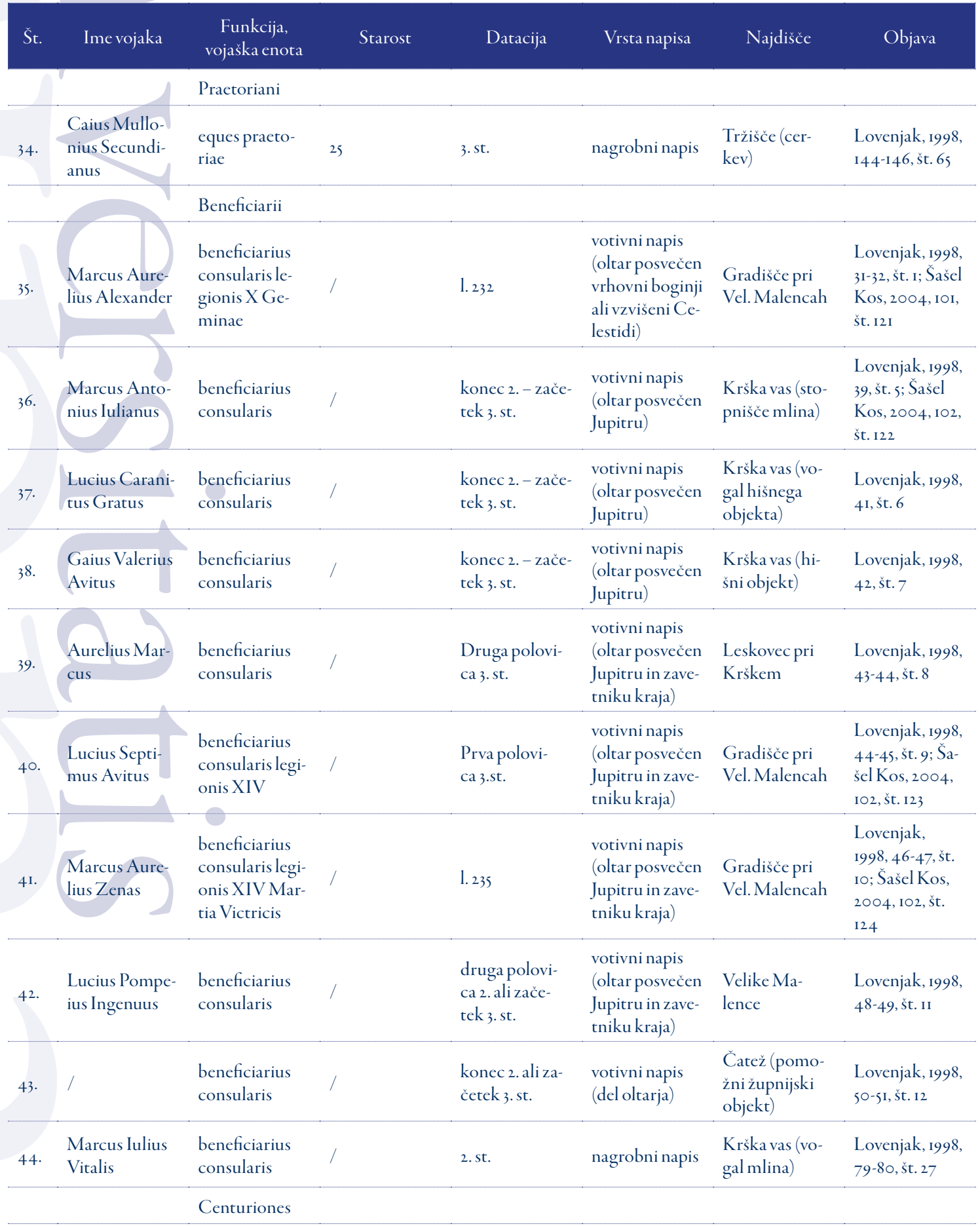




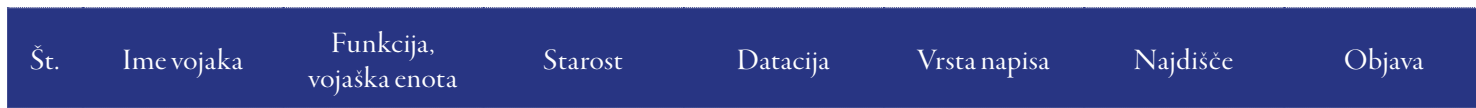

\begin{tabular}{|c|c|c|c|c|c|c|c|}
\hline 45 . & $\begin{array}{l}\text { Maximius } \\
\text { Mansuetus }\end{array}$ & $\begin{array}{l}\text { Centurio legi- } \\
\text { onis XII Ful- } \\
\text { minatae }\end{array}$ & / & verjetno i. st. & nagrobni napis & $\begin{array}{l}\text { Dobova (cer- } \\
\text { kev) }\end{array}$ & $\begin{array}{l}\text { Lovenjak, 1998, } \\
\text { I 4I-I 42, št. } 64\end{array}$ \\
\hline
\end{tabular}

Mensores

\begin{tabular}{|c|c|c|c|c|c|}
\hline $\begin{array}{l}\text { Publius Maxi- } \\
\text { mius Mater- } \\
\text { nus }\end{array}$ & $\begin{array}{l}\text { Mensor legio- } \\
\text { nis X Geminae }\end{array}$ & I. 240 & $\begin{array}{l}\text { votivni napis } \\
\text { (oltar posvečen } \\
\text { rojakom) }\end{array}$ & $\begin{array}{l}\text { Valična vas } \\
\text { (cerkev sv. } \\
\text { Martina) }\end{array}$ & $\begin{array}{l}\text { Lovenjak, 1998, } \\
\text { 132-133, št. } 60\end{array}$ \\
\hline
\end{tabular}

Milites

$\begin{array}{ll}\text { 47. } \begin{array}{l}\text { Vibius Eme- } \\ \text { ritus }\end{array} & \begin{array}{l}\text { miles legionis } \\ \text { X Geminae }\end{array} \\ & \text { Veterani }\end{array}$

\begin{tabular}{|c|c|c|c|c|c|c|c|}
\hline 48. & $\begin{array}{l}\text { Lucius Mar- } \\
\text { cius Blandus }\end{array}$ & $\begin{array}{l}\text { veteranus ex } \\
\text { decurio... No- } \\
\text { ricorum }\end{array}$ & / & $\begin{array}{l}\text { prva polovica } \\
\text { 2. st. }\end{array}$ & nagrobni napis & $\begin{array}{l}\text { Veliki Korinj } \\
\text { (cerkev) }\end{array}$ & $\begin{array}{l}\text { I998, I } 40-141 \text { I, } \\
\text { št. 63; Šašel } \\
\text { Kos, 2004, 105, } \\
\text { št. } 139\end{array}$ \\
\hline 49. & $\begin{array}{l}\text { Caius Mullo- } \\
\text { nius Verus }\end{array}$ & $\begin{array}{l}\text { veteranus le- } \\
\text { gionis X Ge- } \\
\text { minae }\end{array}$ & / & 3. st. & nagrobni napis & $\begin{array}{l}\text { Tržišče (cer- } \\
\text { kev) }\end{array}$ & $\begin{array}{l}\text { Lovenjak, } 1998, \\
\text { I44-I 46, št. } 65\end{array}$ \\
\hline
\end{tabular}

grobnik dal postaviti v čast svoji tašči in materi Juliji Pompeji. ${ }^{17} \mathrm{Na}$ napisu je navedeno, da je Mansuet službo centuriona opravljal v dvanajsti Bliskoviti legiji. Datacijo nagrobnika je Lovenjak postavil v čas okoli i. st. ${ }^{18}$ Vendar pa Kasij Dion v svoji Rimski zgodovini legijo navaja v povezavi z nevihto, ki je vojake rešila pred neizbežnim porazom. Kasij Dionova navedba časovno in prostorsko dvanajsto Bliskovito legijo postavlja v leto 172 n. št, ko se je ta iz Melitene v Kapadokiji (Cappadocia; današnja provinca Nevşehir, Turčija) odpravila na vojaški pohod z Markom Avrelijem proti Kvadom na območje današnje Slovaške. ${ }^{19}$ Vojaški pohod je verjetno potekal tudi preko ozemlja današnje Slovenije in se nadaljeval proti severu, zato je možno, da je Man-

\footnotetext{
17 Lovenjak, Situla, Volume 37: Neviodunum - Inscriptiones Latinae Slovenia (ILSl) I, I 4 I-I 42 .

I8 Lovenjak, Situla, Volume 37: Neviodunum - Inscriptiones Latinae Slovenia (ILSl) I, 142 .

I9 Cassius Dio, Rhomaike historiae, $72=7$ 1.8-10.
}

suet poveljeval eni od centurij namenjeni v boj proti Kvadom in dal v tem obdobju postaviti nagrobni napis. Po Kasiju Dionu je mogoče povzeti, da je Lovenjak datacijo nagrobnika postavil v prezgodnji čas. Nagrobnik je zaradi tega verjetno potrebno umestiti v drugo polovico 2. st., vendar je pri tem potrebno upoštevati, da podrobnosti o vojaškem pohodu in obeh bitkah še niso znani in da je dvanajsta Bliskovita legija nosila to ime že eno stoletje pred omenjenim dogodkom. ${ }^{20}$

V Pretoriju Latobikov (Praetorium Latobicorum; današnje Trebnje) se je od 2. st. n. št. dalje nahajala pomembna prometna postojanka in vojaška točka. ${ }^{21}$ Postaja je upravno pripadala mu-

\footnotetext{
20 Marjeta Šašel Kos, Zgodovinska podoba prostora med Akvilejo, Jadranom in Sirmijem pri Kasiju Dionu in Herodijanu (Ljubljana: Slovenska akademija znanosti in umetnosti, 1986), 247, 249.

2 I Marjeta Šašel Kos, Zgodovinska podoba prostora med Akvilejo, Jadranom in Sirmijem pri Kasiju Dionu in Herodijanu, 377; Iva Mikl Curk, Slavko Ciglenečki and Davorin Vuga, Po poteh rimskih vojakov v Sloveniji (Ljubljana: Zavod Republike Slovenije za varstvo naravne in kulturne dediščine Slovenije, 1993), 47.
} 
Tabela 6: Predstavniki vojakov v Pretoriju Latobikov

\begin{tabular}{|c|c|c|c|c|c|c|c|}
\hline$\check{S}$ t. & Ime vojaka & $\begin{array}{c}\text { Funkcija, } \\
\text { vojaška enota }\end{array}$ & Starost & Datacija & Vrsta napisa & Najdišče & Objava \\
\hline & & Beneficiarii & & & & & \\
\hline 50. & $\begin{array}{l}\text { Caius An- } \\
\text { tistius Threp- } \\
\text { tus }\end{array}$ & $\begin{array}{l}\text { beneficiarius } \\
\text { consularis }\end{array}$ & / & konec 2. ali 3. st. & $\begin{array}{l}\text { votivni napis } \\
\text { (oltar posvečen } \\
\text { Jupitru) }\end{array}$ & Trebnje & $\begin{array}{l}\text { Šašel Kos, } \\
2004,107, \\
\text { št. } 152\end{array}$ \\
\hline 5I. & $\begin{array}{l}\text { Caius An- } \\
\text { tistius Ma- } \\
\text { turus }\end{array}$ & $\begin{array}{l}\text { beneficiarius } \\
\text { consularis }\end{array}$ & l & $\begin{array}{l}\text { verjetno konec } \\
\text { 2. st. }\end{array}$ & $\begin{array}{l}\text { votivni napis } \\
\text { (oltar Jupitru) }\end{array}$ & Trebnje & $\begin{array}{l}\text { Šašel Kos, } \\
2004,107, \\
\text { št. } 153\end{array}$ \\
\hline 52. & $\begin{array}{l}\text { Tiberius Cla- } \\
\text { udius Pereg- } \\
\text { rinus }\end{array}$ & $\begin{array}{l}\text { beneficiarius } \\
\text { consularis }\end{array}$ & / & $\begin{array}{l}\text { konec } 2 \text {. ali za- } \\
\text { četek 3. st. }\end{array}$ & $\begin{array}{l}\text { votivni napis } \\
\text { (oltar posvečen } \\
\text { Jupitru) }\end{array}$ & Trebnje & $\begin{array}{l}\check{S}_{\text {ašel Kos, }} \\
2004,107, \text { št. } \\
\text { I54 }\end{array}$ \\
\hline 53. & $\begin{array}{l}\text { Lucius Clodius } \\
\text { Priscus }\end{array}$ & $\begin{array}{l}\text { beneficiarius } \\
\text { legati consu- } \\
\text { laris }\end{array}$ & / & $\begin{array}{l}\text { konec } 2 \text {. ali za- } \\
\text { četek 3. st. }\end{array}$ & $\begin{array}{l}\text { votivni napis } \\
\text { (oltar posvečen } \\
\text { Jupitru) }\end{array}$ & Trebnje & $\begin{array}{l}\text { Šašel Kos, } \\
2004,108 \text {, št. } 155\end{array}$ \\
\hline 54. & $\begin{array}{l}\text { Titus Iullius } \\
\text { Firminus }\end{array}$ & $\begin{array}{l}\text { beneficiarius } \\
\text { consularis }\end{array}$ & / & druga pol. 2. st. & $\begin{array}{l}\text { votivni napis } \\
\text { (oltar posvečen } \\
\text { Jupitru) }\end{array}$ & Trebnje & $\begin{array}{l}\text { Šašel Kos, } \\
2004,108, \\
\text { št. } 156\end{array}$ \\
\hline 55. & $\begin{array}{l}\text { Caius Nove- } \\
\text { tius Restitutus }\end{array}$ & $\begin{array}{l}\text { ex benecifia- } \\
\text { rius consularis } \\
\text { veteranus legi- } \\
\text { onis I Adiutri- } \\
\text { cis }\end{array}$ & / & $\begin{array}{l}\text { konec } 2 \text { ali za- } \\
\text { četek 3. st. }\end{array}$ & $\begin{array}{l}\text { votivni napis } \\
\text { (oltar posvečen } \\
\text { Jupitru) }\end{array}$ & Trebnje & $\begin{array}{l}\text { Šašel Kos, } \\
2004,108, \text { št. } \\
\text { I57 }\end{array}$ \\
\hline 56. & $\begin{array}{l}\text { Marcus Vi- } \\
\text { ctorius Victo- } \\
\text { rinus }\end{array}$ & $\begin{array}{l}\text { beneficiarius } \\
\text { consularis }\end{array}$ & / & 1. 195 & $\begin{array}{l}\text { votivni napis } \\
\text { (oltar posvečen } \\
\text { Jupitru) }\end{array}$ & Trebnje & $\begin{array}{l}\text { Šašel Kos, } \\
2004,108, \\
\text { št. }{ }^{5} 8\end{array}$ \\
\hline 57. & $\begin{array}{l}\text { Marcus Aure- } \\
\text { lius Valentinus }\end{array}$ & $\begin{array}{l}\text { beneficiarius } \\
\text { consularis legi- } \\
\text { onis XIV Ge- } \\
\text { minae }\end{array}$ & / & $\begin{array}{l}\text { I. november } \\
247 / 248\end{array}$ & $\begin{array}{l}\text { votivni napis } \\
\text { (oltar posvečen } \\
\text { Jupitru Doli- } \\
\text { henskemu) }\end{array}$ & Trebnje & $\begin{array}{l}\text { Šašel Kos, } \\
2004,108, \\
\text { št. } 159\end{array}$ \\
\hline 58. & $\begin{array}{l}\text { Gaius Baebius } \\
\text { Marcellinus }\end{array}$ & $\begin{array}{l}\text { beneficiarius } \\
\text { consularis le- } \\
\text { gionis X Ge- } \\
\text { minae }\end{array}$ & l & 8. april 225 & $\begin{array}{l}\text { votivni napis } \\
\text { (oltar posvečen } \\
\text { Jupitru in vsem } \\
\text { drugim bogo- } \\
\text { vom in zavetni- } \\
\text { ku kraja) }\end{array}$ & Trebnje & $\begin{array}{l}\text { Šašel Kos, } \\
2004,109, \text { št. } \\
160\end{array}$ \\
\hline 59. & $\begin{array}{l}\text { Iulius Teren- } \\
\text { tius }\end{array}$ & $\begin{array}{l}\text { beneficiarius } \\
\text { consularis le- } \\
\text { gionis X Ge- } \\
\text { minae Severi- } \\
\text { anae }\end{array}$ & / & 6. oktober 224 & $\begin{array}{l}\text { votivni napis } \\
\text { (oltar posvečen } \\
\text { vsem bogovom } \\
\text { in zavetniku } \\
\text { kraja) }\end{array}$ & $\begin{array}{l}\text { Sv. Štefan pri } \\
\text { Trebnjem }\end{array}$ & $\begin{array}{l}\text { Šašel Kos, } \\
2004,109, \\
\text { št. I61 }\end{array}$ \\
\hline
\end{tabular}




Št. Ime vojaka $\begin{gathered}\text { Funkcija, } \\ \text { vojaška enota }\end{gathered} \quad$ Starost $\quad$ Datacija $\quad$ Vrsta napisa $\quad$ Najdišče $\quad$ Objava

\begin{tabular}{|c|c|c|c|c|c|c|c|}
\hline 60. & $\begin{array}{l}\text { Aurelius Se- } \\
\text { cundianus / } \\
\text { Itrius }\end{array}$ & $\begin{array}{l}\text { beneficiarius } \\
\text { consularis le- } \\
\text { gionis X Ge- } \\
\text { minae }\end{array}$ & / & 18. maj, 3. st. & $\begin{array}{l}\text { votivni napis } \\
\text { (oltar posvečen } \\
\text { Jupitru in zave- } \\
\text { tniku kraja) }\end{array}$ & Trebnje & $\begin{array}{l}\text { Šašel Kos, } \\
2004,109, \text { št. } \\
162\end{array}$ \\
\hline 6I. & $\begin{array}{l}\text { Marcus Aure- } \\
\text { lius Valentinus }\end{array}$ & $\begin{array}{l}\text { beneficiarius } \\
\text { consularis legi- } \\
\text { onis XIV Ge- } \\
\text { minae }\end{array}$ & / & $\begin{array}{l}\text { I. november, } \\
\text { verjetno } 1.247\end{array}$ & $\begin{array}{l}\text { votivni napis } \\
\text { (oltar posvečen } \\
\text { Jupitru in zave- } \\
\text { tniku kraja) }\end{array}$ & Trebnje & $\begin{array}{l}\text { Šašel Kos, } \\
2004,109 \text {, št. } \\
163\end{array}$ \\
\hline 62. & $\begin{array}{l}\text { Candidius Ur- } \\
\text { sus }\end{array}$ & $\begin{array}{l}\text { beneficiarius } \\
\text { consularis legi- } \\
\text { onis XIV Ge- } \\
\text { minae }\end{array}$ & / & $\begin{array}{l}\text { I5. oktober, } \\
\text { 3. st. }\end{array}$ & $\begin{array}{l}\text { votivni napis } \\
\text { (oltar posvečen } \\
\text { Jupitru in zave- } \\
\text { tniku kraja) }\end{array}$ & Trebnje & $\begin{array}{l}\text { Šašel Kos, } \\
2004, \text { IIO, št. } \\
164\end{array}$ \\
\hline
\end{tabular}

\begin{tabular}{|c|c|c|c|c|c|c|}
\hline $\begin{array}{l}\text { Gaius Iulius } \\
\text { Dignus }\end{array}$ & $\begin{array}{l}\text { beneficiarius } \\
\text { consularis le- } \\
\text { gionis X Ge- } \\
\text { minae }\end{array}$ & / & I. oktober 250 & $\begin{array}{l}\text { votivni napis } \\
\text { (oltar posvečen } \\
\text { Jupitru in zave- } \\
\text { tniku kraja) }\end{array}$ & Trebnje & $\begin{array}{l}\text { Šašel Kos, } \\
2004, \text { IIO, št. } \\
165\end{array}$ \\
\hline
\end{tabular}

\begin{tabular}{|c|c|c|c|c|c|c|}
\hline $\begin{array}{ll}\text { 6aius Iulius } & \text { C. } \\
\text { Impetratus }\end{array}$ & $\begin{array}{l}\text { beneficiarius } \\
\text { consularis le- } \\
\text { gionis X Ge- } \\
\text { minae }\end{array}$ & / & 15. oktober 257 & $\begin{array}{l}\text { votivni napis } \\
\text { (oltar posvečen } \\
\text { Jupitru in zave- } \\
\text { tniku kraja) }\end{array}$ & Trebnje & $\begin{array}{l}\text { Šašel Kos, } \\
2004, \text { IIO, št. } \\
166\end{array}$ \\
\hline
\end{tabular}

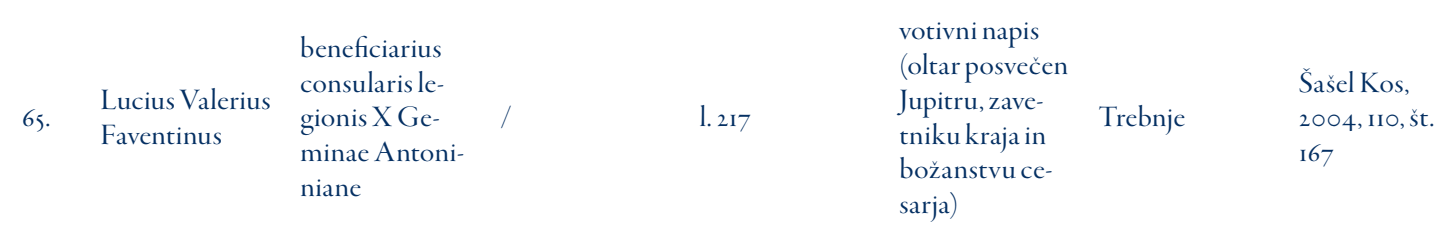

\begin{tabular}{|c|c|c|c|c|c|c|c|}
\hline 66. & $\begin{array}{l}\text { Lucius Varius } \\
\text { Suiranus }\end{array}$ & $\begin{array}{l}\text { beneficiarius } \\
\text { consularis }\end{array}$ & / & $\begin{array}{l}\text { 29. september } \\
240\end{array}$ & $\begin{array}{l}\text { votivni napis } \\
\text { (oltar oltar pos- } \\
\text { večen Jupitru } \\
\text { in zavetniku } \\
\text { kraja) }\end{array}$ & Trebnje & $\begin{array}{l}\text { Šašel Kos, } \\
2004 \text {, III, št. } 168\end{array}$ \\
\hline 67. & / & $\begin{array}{l}\text { beneficiarius } \\
\text { consularis }\end{array}$ & / & 1.232 & $\begin{array}{l}\text { votivni napis } \\
\text { (spodnji del ol- } \\
\text { tarja) }\end{array}$ & Trebnje & $\begin{array}{l}\text { Šašel Kos, } \\
2004, \text { III, št. } 169\end{array}$ \\
\hline
\end{tabular}

nicipiju Nevioduna, vendar se je ta nahajala v neposredni bližini meje med provinco Panonijo in
Deseto italsko regijo, ki je potekala na območju današnje Stične. ${ }^{2}$

22 Marjeta Šašel Kos, "Cestni postaji Atrans in Pretorij Latobikov," in Zakladi tisočletij, ur. Bronislava Aubelj (Ljubljana: Modrijan, 1999), 239. 
Tabela 7: Predstavniki beneficiarijevv Celeji

\begin{tabular}{|c|c|c|c|c|c|}
\hline$\check{S}_{\mathrm{t}}$ & Ime beneficiarja & $\begin{array}{c}\text { Funkcija, } \\
\text { vojaška enota }\end{array}$ & Starost & Datacija & Prokurator \\
\hline & $\begin{array}{l}\text { Beneficiarii procura- } \\
\text { toris }\end{array}$ & & & & \\
\hline 68. & & $\begin{array}{l}\text { beneficiarius pro- } \\
\text { curator }\end{array}$ & / & 1. 110 & Memmius Apolinaris \\
\hline 69. & Antonius Maximus & $\begin{array}{l}\text { beneficiarius pro- } \\
\text { curator }\end{array}$ & / & 2. ali 3. desetletje 2. st. & Q. Caecilius Redditus \\
\hline 70. & L. Messius Frontinus & $\begin{array}{l}\text { beneficiarius pro- } \\
\text { curator }\end{array}$ & / & $\begin{array}{l}\text { I20 do neposredno } \\
\text { po } 135\end{array}$ & C. Censorius Niger \\
\hline $7 \mathrm{I}$. & M. Ulpius Crescens & $\begin{array}{l}\text { beneficiarius pro- } \\
\text { curator }\end{array}$ & / & $120-130$ & C. Censorius Niger \\
\hline 72. & Nonius? Primus & $\begin{array}{l}\text { beneficiarius pro- } \\
\text { curator }\end{array}$ & / & okoli i40 & Plautius Caesianus \\
\hline 73. & Masclinius Successus & $\begin{array}{l}\text { beneficiarius pro- } \\
\text { curator }\end{array}$ & / & prva polovica 2. st. & C. Antistius Auspex \\
\hline 74 & Augustanus & $\begin{array}{l}\text { beneficiarius pro- } \\
\text { curator }\end{array}$ & / & prva polovica 2. st. & C. Rasinius Silo \\
\hline 75 . & Gemellius Adiutor & $\begin{array}{l}\text { beneficiarius pro- } \\
\text { curator }\end{array}$ & / & prva polovica 2. st. & Drusius Proculus \\
\hline 76 & $\begin{array}{l}\text { Q. Crescentius Mar- } \\
\text { cellus }\end{array}$ & $\begin{array}{l}\text { beneficiarius pro- } \\
\text { curator }\end{array}$ & / & prva polovica 2. st. & Q. Lisinius Sabinus \\
\hline 77. & T. Flavius Dubitatus & $\begin{array}{l}\text { beneficiarius pro- } \\
\text { curator }\end{array}$ & / & prva polovica 2. st. & Q. Lisinius Sabinus \\
\hline 78. & C.Mustius Tettianus & $\begin{array}{l}\text { beneficiarius pro- } \\
\text { curator }\end{array}$ & / & prva polovica 2. st. & Lisinius Sabinus \\
\hline 79. & Lucilius Finitus & $\begin{array}{l}\text { beneficiarius pro- } \\
\text { curator }\end{array}$ & / & okoli I52-153 & Flavius Titianus \\
\hline 80. & C. An $(\mathrm{t})$ onius Valens & $\begin{array}{l}\text { beneficiarius pro- } \\
\text { curator }\end{array}$ & / & $152-153$ & Flavius Titianus \\
\hline $8 \mathrm{I}$ & C. Fuscinius Catullus & $\begin{array}{l}\text { beneficiarius pro- } \\
\text { curator }\end{array}$ & / & $154-158$ & Ulpius Victor \\
\hline 82. & Adnamius Flavinus & $\begin{array}{l}\text { beneficiarius pro- } \\
\text { curator }\end{array}$ & / & okoli 158 & Ulpius Victor \\
\hline 83. & Adnamius Flavinus & $\begin{array}{l}\text { beneficiarius pro- } \\
\text { curator }\end{array}$ & / & okoli 158 & Usenius Secundus \\
\hline 84. & Q. Kaninius Lucanus & $\begin{array}{l}\text { beneficiarius pro- } \\
\text { curator }\end{array}$ & / & 158 & Usenius Secundus \\
\hline
\end{tabular}




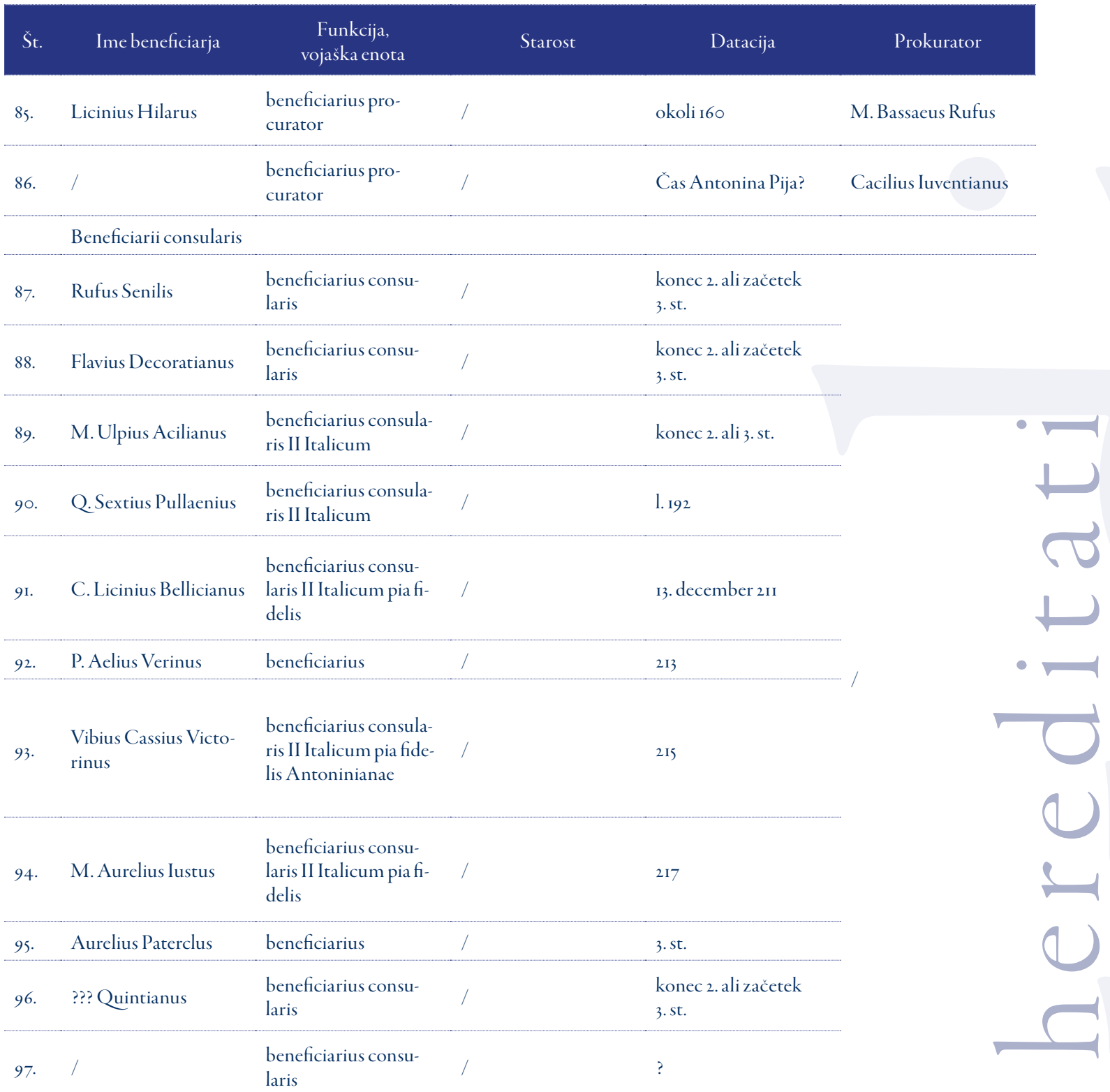

Vojaške napise iz Pretorija Latobikov in njegove okolice v celoti (osemnajst napisov) sestavljajo beneficiarski napisi. Med prevladujočimi napisi konzularjevih beneficiarijev sta po enkrat izpričana tudi konzularjev legat (št. 53) in nekdanji konzularjev beneficiarij, ki je na napis poleg oznake ex beneficiario consularis dodal tudi status veterana prve Pomožne legije (št. 55). Poleg omenjene legije sta na desetih primerih navede- ni še dve vojaški enoti. Štirinajsta Dvojna legija je izpričana na treh napisih (št. 57, 6I in 62), vendar glede na ime in datacijo lahko sklepamo, da je napisa št. 57 in 6I dala postaviti ista oseba. Deseta Dvojna legija je izpričana na napisih št. 58 , $59,60,63,64,65$ in 66 . Na napisu št. 58 je ime legije dopolnjeno z vzdevkom Severiana, po cesarski dinastiji Severov, na napisu št. 66 pa z Antoniniana, po cesarski dinastiji Antoninov. Oznaka 
Tabela 8: Predstavniki beneficiarijev v Celeji ${ }^{\mathrm{I}}$

\begin{tabular}{|c|c|c|c|c|c|}
\hline$\check{S}_{\mathrm{t}}$. & Ime beneficiarja & $\begin{array}{c}\text { Funkcija, } \\
\text { vojaška enota }\end{array}$ & Starost & Datacija & Prokurator \\
\hline & $\begin{array}{l}\text { Beneficiarii procura- } \\
\text { toris }\end{array}$ & & & & \\
\hline 68. & & $\begin{array}{l}\text { beneficiarius pro- } \\
\text { curator }\end{array}$ & / & l. 110 & Memmius Apolinaris \\
\hline 69. & Antonius Maximus & $\begin{array}{l}\text { beneficiarius pro- } \\
\text { curator }\end{array}$ & / & 2. ali 3. desetletje 2. st. & Q. Caecilius Redditus \\
\hline 70. & L. Messius Frontinus & $\begin{array}{l}\text { beneficiarius pro- } \\
\text { curator }\end{array}$ & / & $\begin{array}{l}120 \text { do neposredno } \\
\text { po } 135\end{array}$ & C. Censorius Niger \\
\hline $7 \mathrm{I}$. & M. Ulpius Crescens & $\begin{array}{l}\text { beneficiarius pro- } \\
\text { curator }\end{array}$ & / & $120-130$ & C. Censorius Niger \\
\hline 72. & Nonius? Primus & $\begin{array}{l}\text { beneficiarius pro- } \\
\text { curator }\end{array}$ & / & okoli I 40 & Plautius Caesianus \\
\hline 73. & Masclinius Successus & $\begin{array}{l}\text { beneficiarius pro- } \\
\text { curator }\end{array}$ & / & prva polovica 2. st. & C. Antistius Auspex \\
\hline 74. & Augustanus & $\begin{array}{l}\text { beneficiarius pro- } \\
\text { curator }\end{array}$ & / & prva polovica 2. st. & C. Rasinius Silo \\
\hline 75 . & Gemellius Adiutor & $\begin{array}{l}\text { beneficiarius pro- } \\
\text { curator }\end{array}$ & / & prva polovica 2. st. & Drusius Proculus \\
\hline 76. & $\begin{array}{l}\text { Q. Crescentius Mar- } \\
\text { cellus }\end{array}$ & $\begin{array}{l}\text { beneficiarius pro- } \\
\text { curator }\end{array}$ & / & prva polovica 2. st. & Q. Lisinius Sabinus \\
\hline 77. & T. Flavius Dubitatus & $\begin{array}{l}\text { beneficiarius pro- } \\
\text { curator }\end{array}$ & / & prva polovica 2. st. & Q. Lisinius Sabinus \\
\hline 78. & C.Mustius Tettianus & $\begin{array}{l}\text { beneficiarius pro- } \\
\text { curator }\end{array}$ & / & prva polovica 2. st. & Lisinius Sabinus \\
\hline 79. & Lucilius Finitus & $\begin{array}{l}\text { beneficiarius pro- } \\
\text { curator }\end{array}$ & / & okoli I52-153 & Flavius Titianus \\
\hline $8 \circ$. & C. An $(\mathrm{t})$ onius Valens & $\begin{array}{l}\text { beneficiarius pro- } \\
\text { curator }\end{array}$ & / & $152-153$ & Flavius Titianus \\
\hline $8 \mathrm{I}$. & C. Fuscinius Catullus & $\begin{array}{l}\text { beneficiarius pro- } \\
\text { curator }\end{array}$ & / & $154-158$ & Ulpius Victor \\
\hline 82. & Adnamius Flavinus & $\begin{array}{l}\text { beneficiarius pro- } \\
\text { curator }\end{array}$ & / & okoli 158 & Ulpius Victor \\
\hline 83. & Adnamius Flavinus & $\begin{array}{l}\text { beneficiarius pro- } \\
\text { curator }\end{array}$ & / & okoli 158 & Usenius Secundus \\
\hline
\end{tabular}

Visočnik, "Vojaški napisi iz Celeje in njene okolice", 337. 


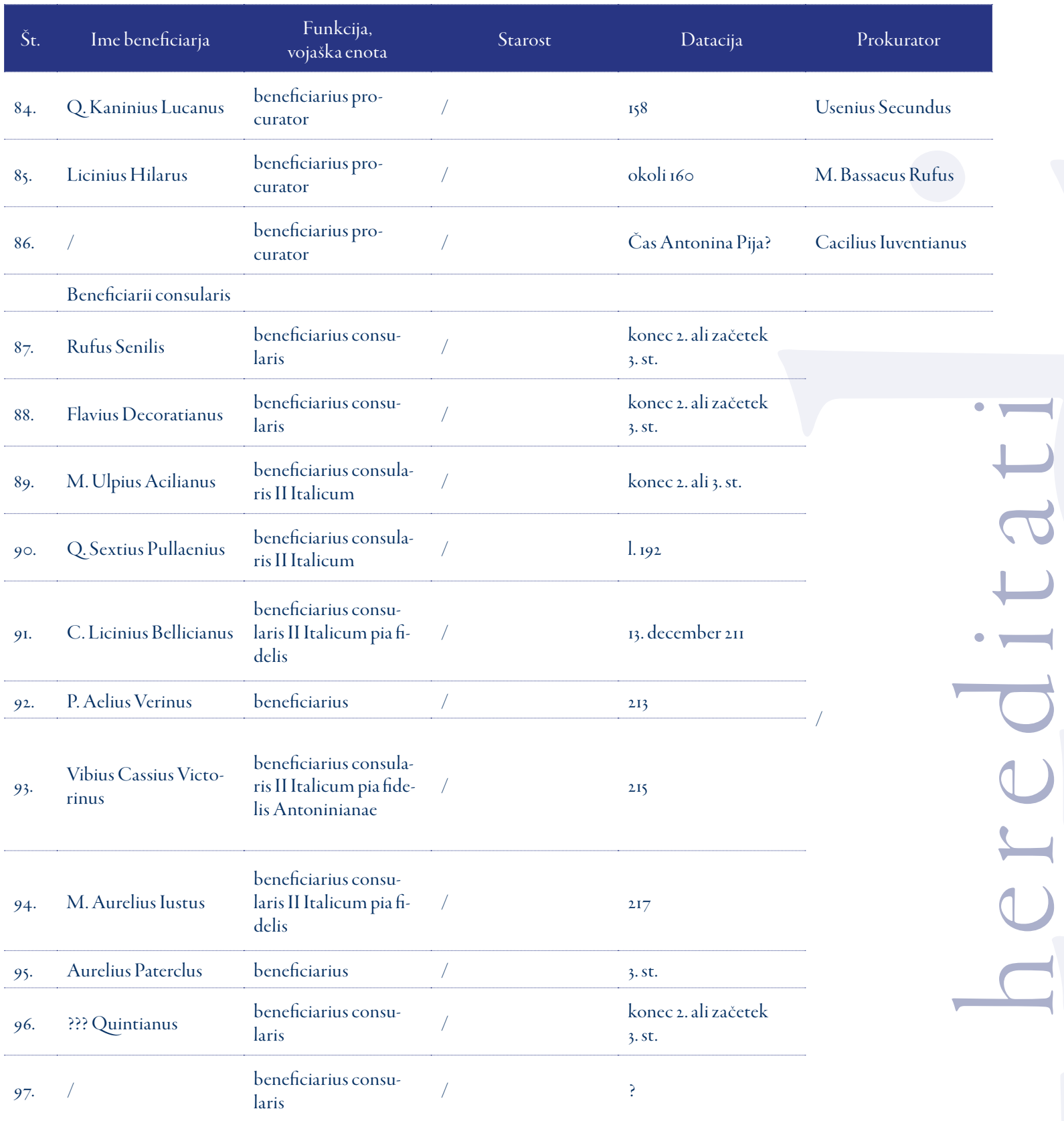

miles se pojavi tudi na oltarju konzularjevega beneficiarija Gaja Bebija Marcelina (št. 58).

Z območja Celeje se beneficiarski napisi delijo na dve skupini: na prokuratorjeve (do markomanskih vojn) in konzularjeve, ko provinco ni več upravljal prokurator, ampak legat. ${ }^{23}$

23 Visočnik, "Vojaški napisi iz Celeje in njene okolice", 335. 
Tabela 9: Predstavniki vojske na posamičnih lokacijah po Sloveniji
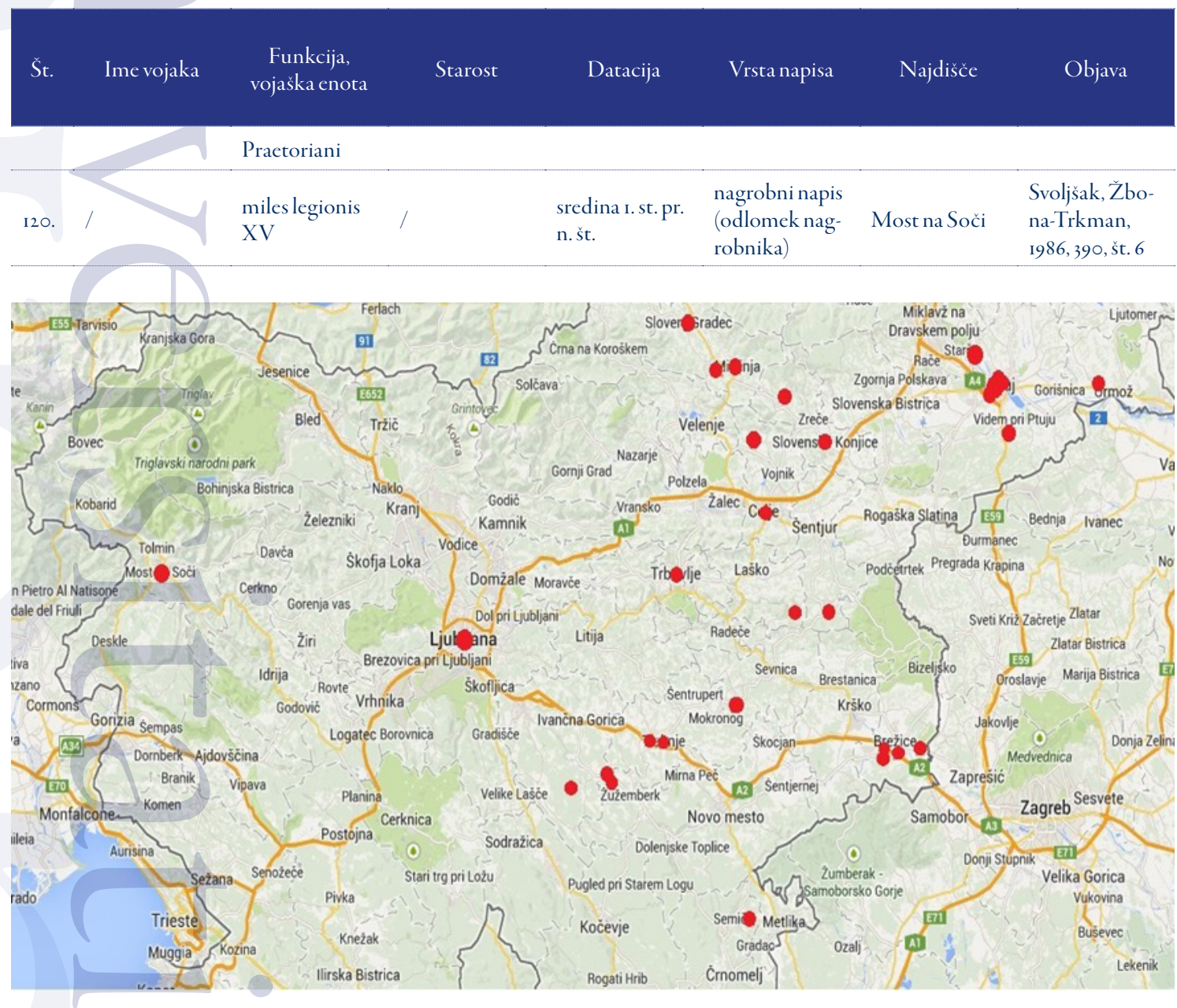

Slika I:Zemljevid, ki prikazuje število vojaških napisov na prostoru tromeje med Italijo, Norikom in Panonijo (zemljevid prirejen po https://maps.google.com/). 


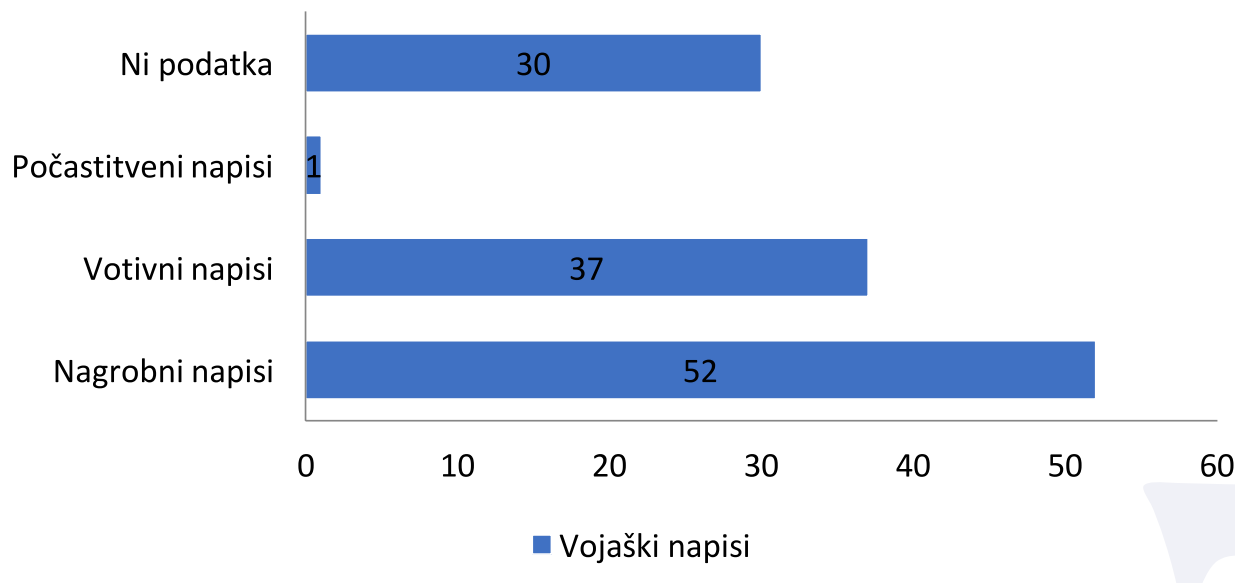

Graf I: Grafični prikaz števila vojaških napisov.

Opomba: V skupino »ni podatka« so vključeni vojaški napisi iz odlomljenih ali poškodovanih spomenikov, na katerih je napisno polje nečitljivo ali popolnoma odstranjeno.
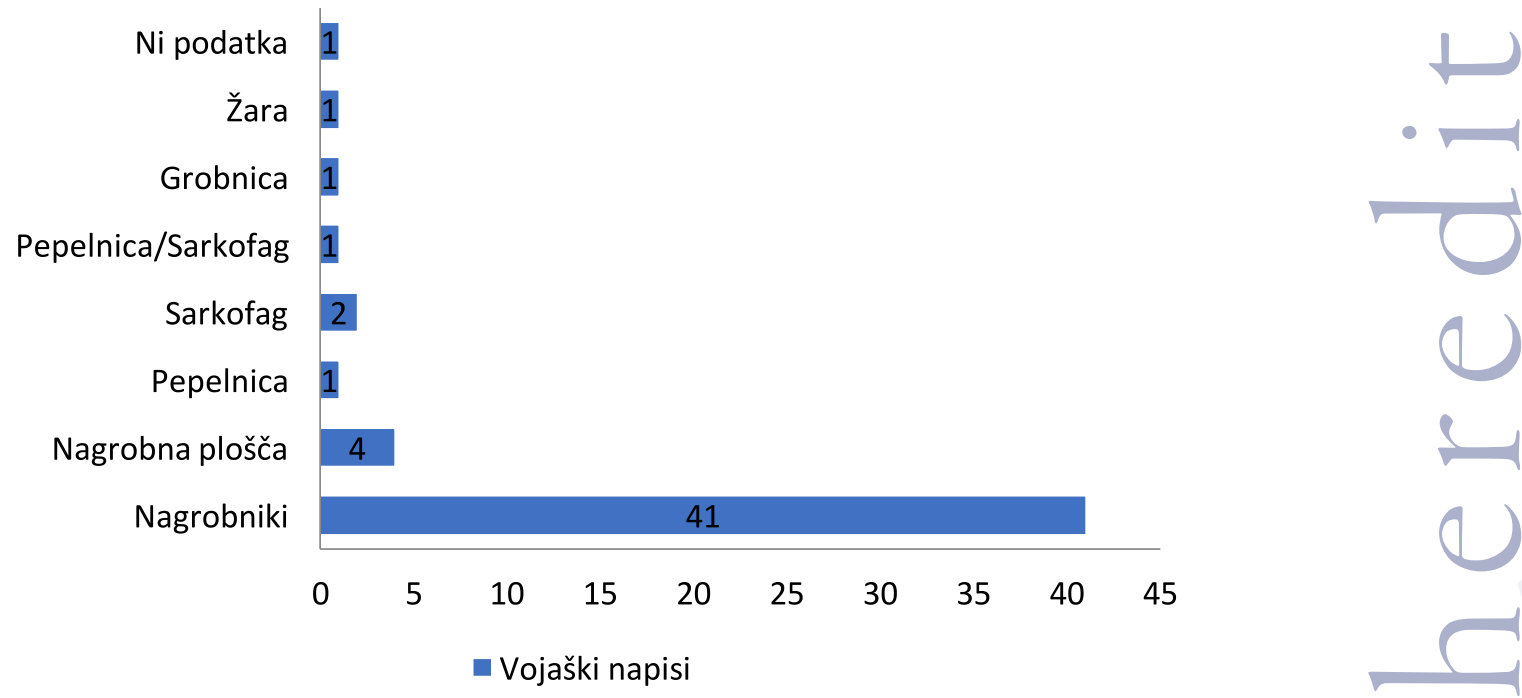

Graf 2: Grafični prikaz števila vojaških napisov glede na vrsto nagrobnega spomenika.

Opomba: V skupino »ni podatka« so vključeni nagrobni napisi iz odlomljenih ali poškodovanih spomenikov, na katerih je pisno polje nečitljivo ali popolnoma odstranjeno. 
Beneficiarii

Beneficiarii procuratores

Beneficiarii legati consularis

Beneficiarii consulari

Mensores

Decuriones

Primi Hastat

Optii

Praefecti

Centuriones

Beneficiarii tribuni

Miles

Veterani

Frumentrari

Signiferi

Praetoriani

Tribuni militium

Emona

0
Poetovio

$\stackrel{5}{\text { Neviodunum }}$

10 rium

- Celeia

Graf 3: Grafični prikaz števila rimskih vojakov na slovenskem prostoru glede na funkcijo.

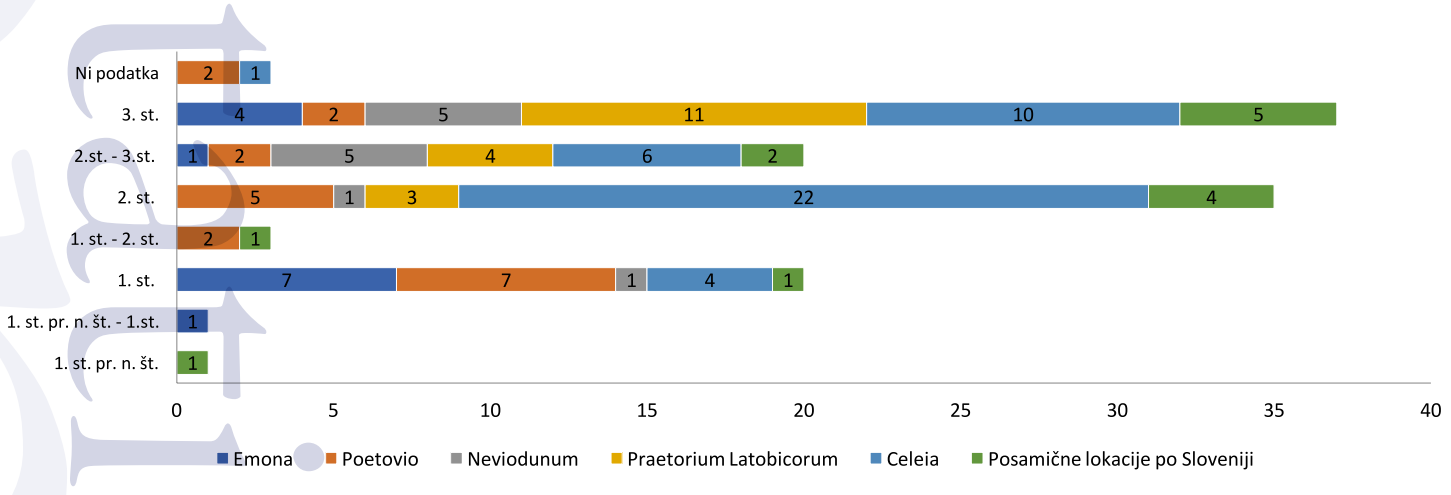

Graf 4: Grafični prikaz števila rimskih vojakov na slovenskem prostoru glede na obdobje.

Opomba: V skupino »ni podatka« so vključeni rimski vojaki iz odlomljenih ali poškodovanih spomenikov, na katerih je datacija nečitljiva ali popolnoma odstranjena. 


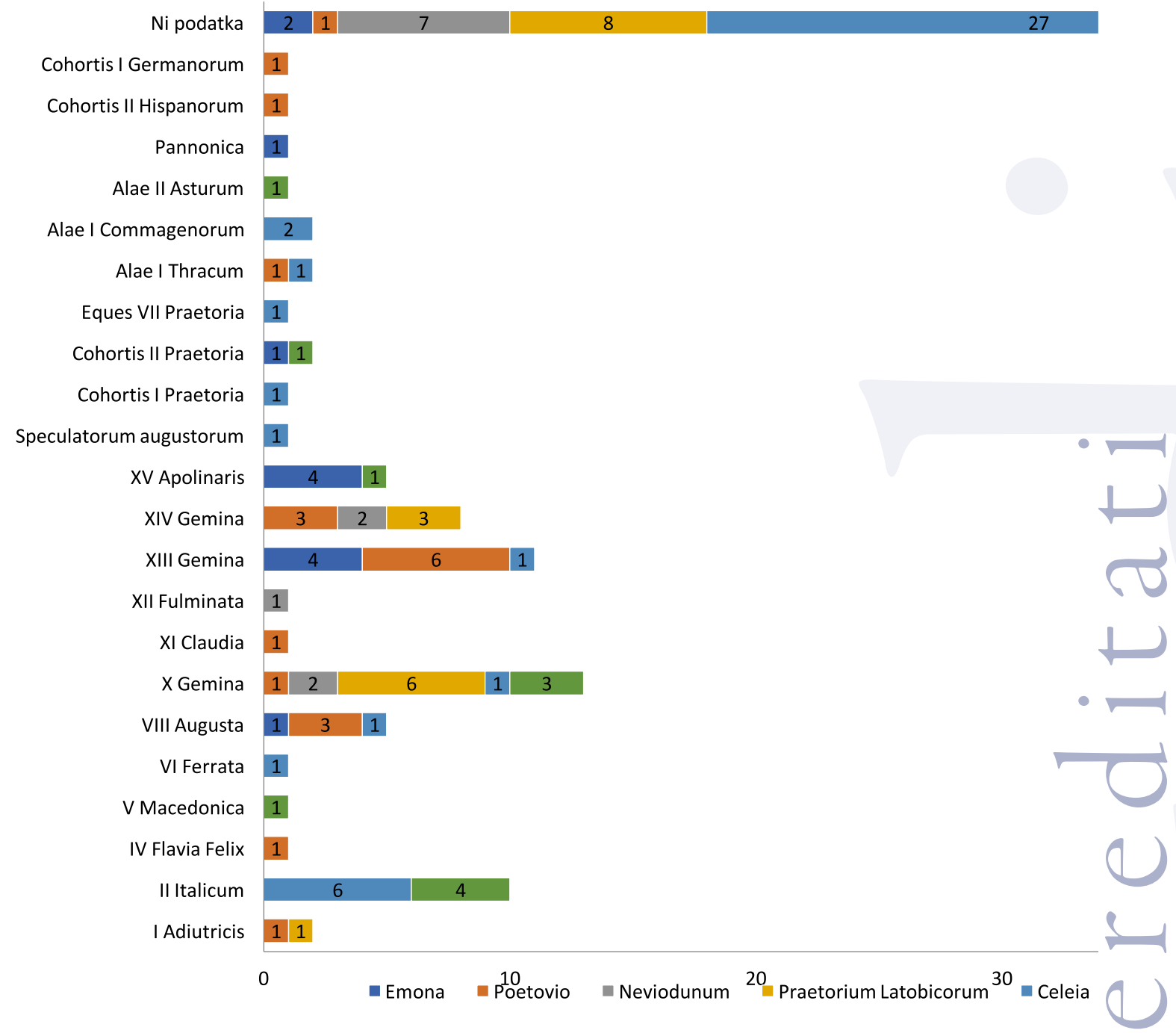

Graf 5: Grafični prikaz rimskih vojaških oddelkov omenjenih na obravnavanih napisih.

Opomba: V skupino »ni podatka« so vključeni rimski vojaki iz odlomljenih ali poškodovanih spomenikov, na katerih so podatki o pripadnosti k vojaškemu oddelku nečitljivi ali popolnoma odstranjeni. 


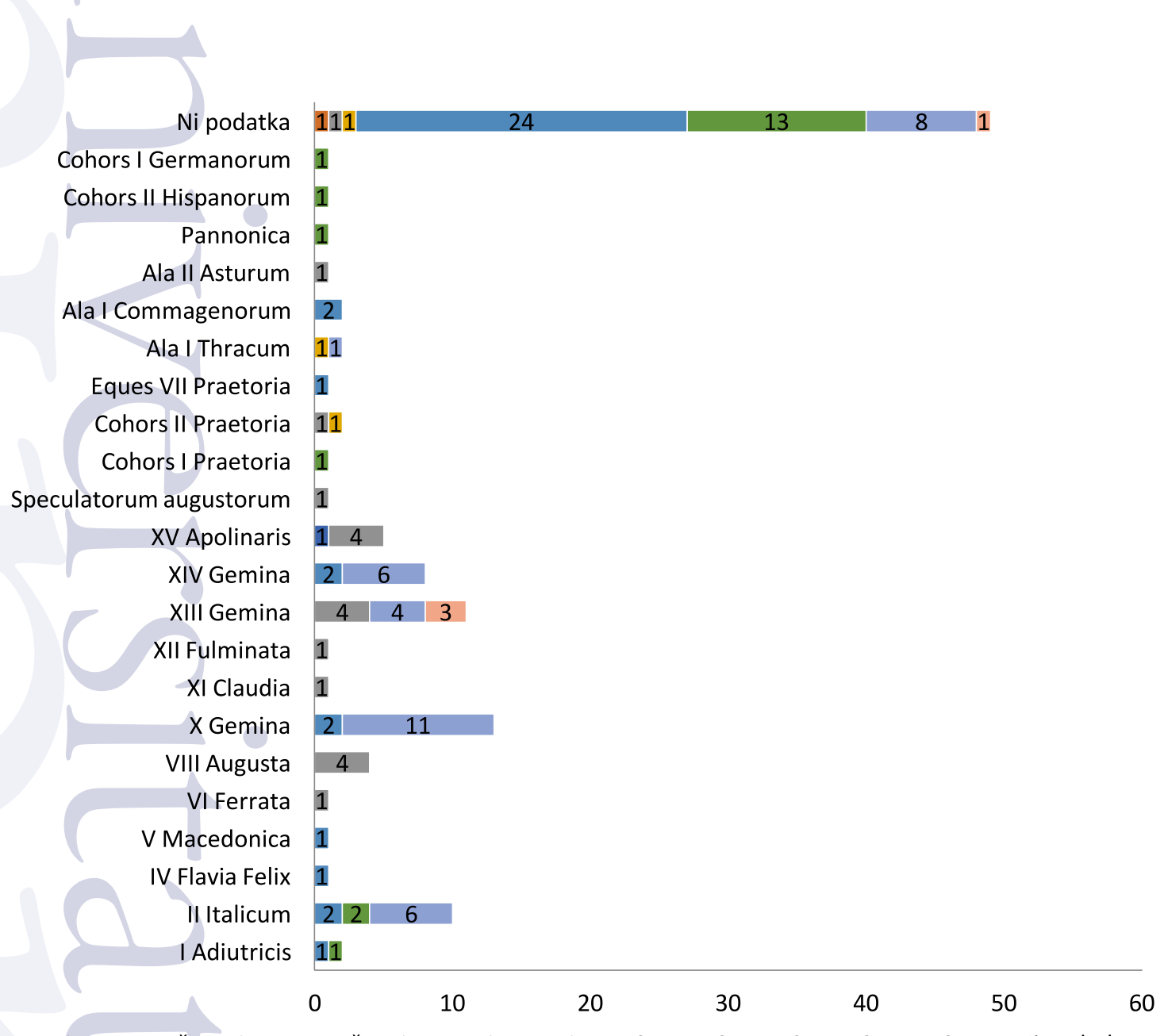

$\square$ 1. st. pr. n. št. $\square$ 1. st. pr. n. št. - 1. st. $\square$ 1. st. $\square 1$. st. - 2. st. $\square$ 2. st $\square$ 2. st. - 3. st. $\square$ 3. st $\square$ Ni podatka

Graf 6: Grafični prikaz rimskih vojaških oddelkov na slovenskem prostoru razvrščcnih po obdobjih.

Opomba: V skupino »ni podatka « so vključeni rimski vojaki iz odlomljenih ali poškodovanih spomenikov, na katerih so podatki o pripadnosti k vojaškemu oddelku nečitljivi ali popolnoma odstranjeni. 


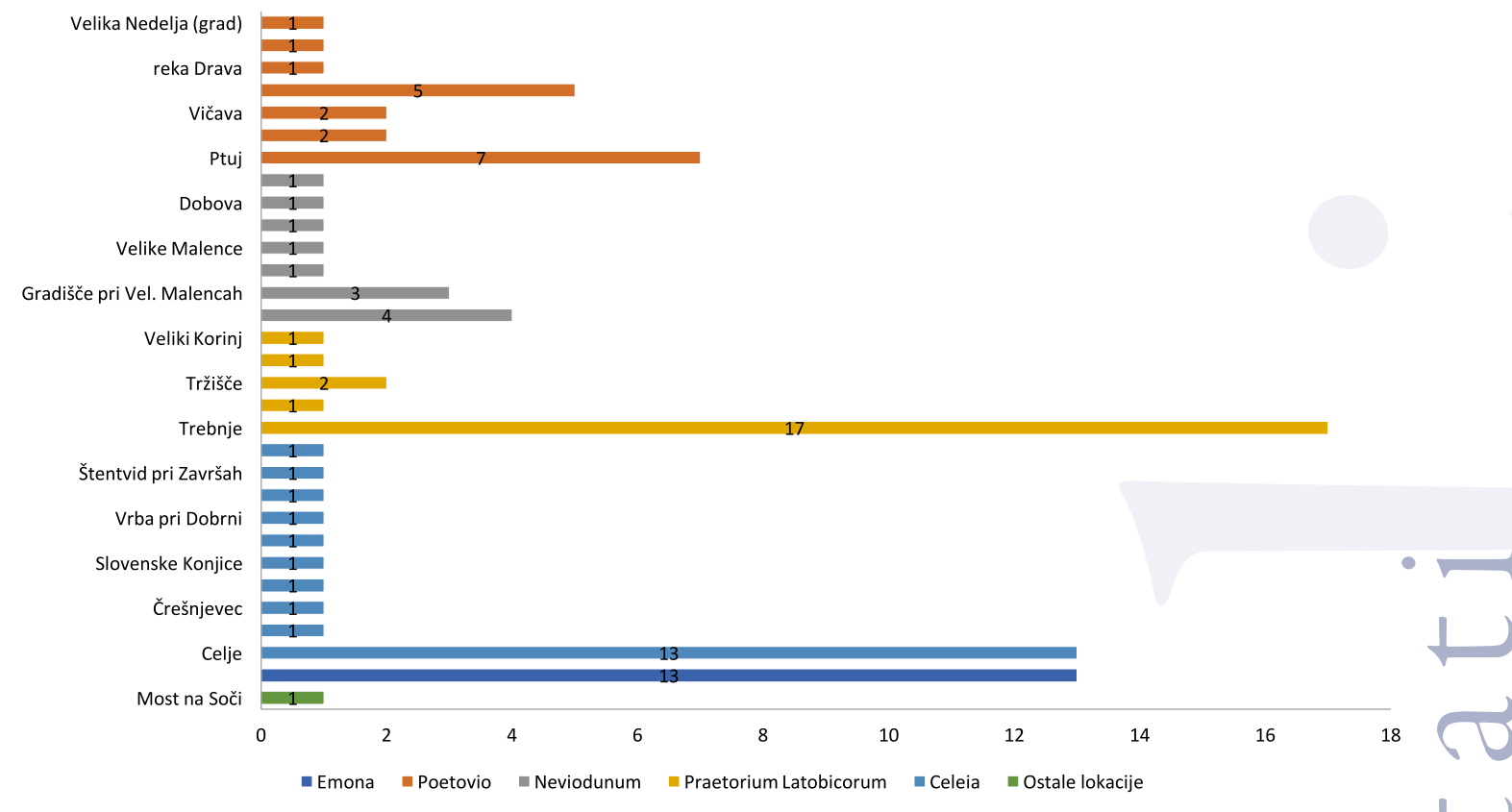

Graf 7: Grafični prikaz najdišč rimskih vojaških napisov v obravnavanem obdobju.

Opomba: V graf niso vključeni beneficiariji iz celejanskega prostora.

\section{Summary}

The large part of military inscriptions is represented by tombstones (gravestones, stelae, sarcophagi, tombs, cremation and cinerary urns) (look chart I and 2), while the lesser part is known from altars and dedications. The latter are votive inscriptions, often dedicated to deities, family members and friends. The overriding message on military inscriptions is primarily of memorial usage, but on some examples soldiers are also mentioned as dedicators or contributors (no. 5, II, I8/19, I06 and II3). Examples no. 21, 27, 44, 45, 49, 98/104, IOI and II9 testify that some soldiers used to order such tombstones during their lifetime for themselves and were later testamentary erected after they passed away.

From everything stated, it is clear that despite the modest number of existing and documented military inscriptions found all over Slovenia, they confirm the presence of Roman soldiers in this area. The increased number of military inscriptions from the $\mathrm{I}^{\mathrm{st}}$ and $2^{\text {nd }}$ century (see chart 4) can be attributed to the intensive expansion of the Roman Empire in the Southeast Europe- an region towards the Balkans and the subsequent war developments within the Empire.

Military inscriptions from Emona, Petovio, Neviodunum, Prateorium Latobicorum, Celeia and other individual locations all over Slovenia mostly belonged to the beneficiarii, common legionaries, praetorians, centurions and veterans; in three cases (no. 48, 55 and II5) it is also clear the function and the department unit in which these veterans served.

On military inscriptions found all over Slovenia are mentioned Apollo's Fifteenth Legion, Augustus' Eighth Legion, Thirteen Twin Legion, Italian Second Legion and individual units of the Hispanic Ninth legion and the Fourteenth Twin legion, the Rescuer First Legion, Lucky Flavian Fourth Legion, Macedonian Fifth Legion, Sixth Ironclad legion, Tenth Twin Legion, the Thunderbolt Twelfth Legion and Thirteenth Twin Legion.

Among praetorian troops the second cohort is mentioned twice, while the first praetorian cohort and the seventh praetorian cavalry cohort only once. Beside praetorian troops, the inscription no. 98 mentions a commander of a reconnaissance unit of praetorians. 
Among inscriptions of auxiliary troops there are also two mentions of the first and second horse unit - alae of Thracians and Commageni, while units of the first Hispanic cohort, first Germanic cohort and the horse unit of Asturi are all mentioned once.

Examples of military inscriptions from Emona of the Ist century AD (see chart 5 and 6) prove only that the Apollo's Fifteenth Legion and the Augustus' Eighth Legion participated in the conquest of the Cisalpine Gaul and the Western Balkan territories against indigenous people. Furthermore evidence can be found on military inscriptions from Petovio, specifically those attributed to the Augustus' Eight Legion (see chart 5 and 6) of which soldiers built a military camp in the vicinity of today's Ptuj.

After the second half of the ist century AD the number of representatives of the Thirteenth Twin Legion is increased among inscriptions (see chart 6). These inscriptions give further evidence to the already known ancient sources about the presence and accommodation of the Thirteenth Twin Legion in Petovio's region. In ancient sources the Thirteen Twin Legion was mentioned by Tacitus in relation to the year of four emperors.

In Neviodunum and Praetorium Latobicorum inscriptions can be connected with the beneficiarii (see chart 3), which in most cases are altars and dedications intended for gods and other deities. Most of the inscriptions are dedicated to Jupiter and several local patrons. On inscriptions no. 3 and 58 , Jupiter is known as Jupiter Dolichenus. In the Roman Empire during the $2^{\text {nd }}$ and $3^{\text {rd }}$ century the cult of Jupiter Dolichenus was widespread especially among soldiers. In Pannonia it flourished during the Severan dynasty. Some examples of these inscriptions were dedicated to individual goddesses (no. 4 , 17,33 and 35 ) or all gods (no. 58 and 59 ) and in one case also to compatriots (no. 46). Most of these votive inscriptions belonged to the beneficiarii and are accurately dated to the $2^{\text {nd }}$ and $3^{\text {rd }}$ century (no. 57, 58, 59, 60, 61, 62, 63, 64 and 66), i.e. during this period in provincial towns the Empire established important offices and institutions, which were managed by the beneficiarii.

None of the dedicators or contributors was an ordinary soldier: Valerius Aemilianus (no. 3) was a sign-bearer, Vibius (no. 4) was a superintendent, Martial (no. 17) and Lucius Septimius Tertinius (no. IO5) were centuri- ons, Gaius Cassius Silvester (no. 33) was a veteran, Publius Maximius Maternus (no. 46) was a measurer and others (no. 35, 36, 37, 38, 39, 40, 41, 42, 43, 44, 45, 50, 51, 52, $53,54,55,56,57,58,59,60,61,62,63,64,65,66$ and 67) were all beneficiarii.

Many roman military inscriptions found all over Slovenia were scattered on different locations in Dolenjska, Bela Krajina (Tržišče, Šmihel near Žužemberk, Veliko Korinje near Žužemberk) and Styria (Črešnjevec, Slovenj Gradec, Slovenske Konjice, Hudinja near Vitanje and Vrba near Dobrna), from which can be concluded, that these places were included in the wider hinterland of provincial towns of Celeia, Petovio and Neviodunum. In the far west of Slovenia, in Grad near Reka was found a cemetery with 149 graves. Among finds there was a tombstone belonging to a military soldier of the Fifteenth Legion (no. 120), dated between 53 and ${ }_{31} \mathrm{BC}$.

Expected differences can be spotted between cities, which are already visible by the number of military inscriptions.

\section{Povzetek}

Velik del vojaških napisov se nahaja na nagrobnikih (nagrobne plošče, stele, sarkofagi, pepelnice, grobnice in žare) (glej graf I in 2), v manjšem številu pa na votivnih napisih (v obliki oltarjev in posvetil). Vojaki na napisih nastopajo kot pokojniki, pa tudi kot postavljavci napisov družinskim članom (št. 5, II, I8/19, IO6 in II3). Kot postavljavci spomenikov so vojaki izpričani tudi na napisih št. 2I, 27, 44, 45, 49, 98/104, IOI in II9, katere so naročili še v času svojega življenja in jih oporočno dali postaviti $\mathrm{v}$ spomin sebi in svojim bližnjim. Iz vsega, kar smo navedli, je razvidno, da kljub skromnemu številu obstoječih in dokumentiranih vojaških napisov najdenih širom Slovenije, ti podpirajo predpostavko o prisotnosti rimskih vojakov na obravnavanem območju. Povečano število napisov vojakov iz I. in 2. st. (glej sl. 5) lahko povežemo z intenzivno širitvijo rimske države na jugovzhodni evropski prostor in naprej na Balkan in kasnejšim vojnim dogajanjem znotraj cesarstva.

$\mathrm{Na}$ obravnavanih vojaških napisih Emone, Petovione, Nevioduna, Prateorija Latobikov, Celeje in drugih posamičnih lokacijah po Sloveniji so izpričani predvsem beneficiariji, legionarji, pretorijanci, centurioni in veterani; v treh primerih (št. 48,55 in II $)$ je pri veteranih ome- 
njena tudi funkcija in oddelek vojaških enot v katerih so službovali.

Poleg petnajste Apolonove, osme Avgustove, trinajste Dvojne, druge Italske legije ter posamičnih enot devete Hispanske in štirinajste Dvojne legije, so na vojaških napisih izpričane še prva Pomožna, četrta Flavia srečna, peta Makedonska, šesta Železna, deseta Dvojna, dvanajsta Bliskovita in trinajsta Dvojna legija.

Med pretorijanskimi četami se Druga pretorijanska kohorta pojavi dvakrat, Prva pretorijanska kohorta in Sedma pretorijanska konjenica pa enkrat. Poleg pretorijanskih čet se v enem primeru (št. 98) pojavi tudi poveljnik izvidniške enote pretorijancev. Med pomožnimi četami se prva ala Komagenov in druga ala Tračanov pojavita dvakrat, po enkrat pa prva germanska in prva hispanska kohorta ter druga ala Asturov.

Primeri vojaških napisov iz Emone v I. st. n. št. (glej sl. 6 in 7) dokazujejo zgolj to, da sta petnajsta Apolonova in osma Avgustova legija sodelovali pri osvajanju jugovzhodno alpskega in zahodno balkanskega prostora $\mathrm{v}$ boju proti avtohtonemu prebivalstvu. Podobno ugotovitev lahko razberemo tudi iz vojaških napisov iz Petovione, med katerimi po številu prevladujejo napisi osme Avgustove legije (glej sl. 6 in 7), ki je v okolici današnjega Ptuja postavila vojaški tabor. Iz druge polovice i. st. n. št. so na napisih največkrat izpričani predstavniki trinajste Dvojne legije (glej sl. 7). Njihova omemba predstavlja dodaten dokaz o prisotnosti in nastanitvi trinajste Dvojne legije na lokaciji, ki jo v antičnih virih omenja Tacit $\mathrm{v}$ povezavi z letom štirih cesarjev.

Iz stališča preučevanja rimskih vojaških napisov, sta pomembna tudi Neviodunum in Pretorij Latobikov, kjer številčno prevladujejo beneficiarski napisi (glej sl. 4), ki so v večini primerov oltarji ali posvetila namenjena božanstvom. Največkrat so napisi posvečeni Jupitru in lokalnim zavetnikom kraja. Na napisih št. 3 in 58 je Jupiter poimenovan kot Jupiter Dolihenski. Dolihenov kult je bil po imperiju razširjen posebej med vojaštvom v 2. in 3. st. V Panoniji je doživel razcvet v času dinastije Severov. Na nekaterih primerih so napisi posvečeni posameznim boginjam (št. 4, 17, 33 in 35) ali vsem bogovom (št. 58 in 59) in v enem primeru tudi rojakom (št. 46). Večina votivnih napisov je natančno datiranih (št. 57, 58, 59, 60, 6I, $62,63,64$ in 66). Največ beneficiarskih napisov je datiranih v čas 2. in 3. st., kar dokazuje, da so bili v tem obdobju $\mathrm{v}$ provincialnih mestih ustanovljeni pomembni uradi in druge institucije, ki so jih morda upravljali beneficiariji. Med te iz našega območja nedvomno prištevamo beneficiarsko postajo Pretorija Latobikov. Nobeden od posvetiteljev votivnih napisov ni bil navaden vojak: Valerij Emiljan (št. 3) je bil nosilec znaka, Vibij (št. 4) je bil intendant, Marcijial (št. 17) in Lukij Septimij Tertin (št. IO5) sta bila centuriona, Gaj Kasij Silvester (št. 33) je bil veteran, Publij Maskimij Matern (št. 46) je bil merilec, ostali (št. 35, 36, 37, 38, 39, 40, 4I, 42, 43, 44, 45, 50, 51, 52, 53, 54, $55,56,57,58,59,60,61,62,63,64,65,66$ in 67) pa so bili beneficiariji.

Najdišča vojaških napisov z območja slovenskega prostora so znana tudi na posamičnih lokacijah po Dolenjski in Beli Krajini (npr. v Tržiščcu, Šmihelu pri Žužemberku in Velikemu Korinju pri Žužemberku) ter štajerskega prostora (npr. Črešnjevec, Slovenj Gradec, Slovenske Konjice, Hudinja pri Vitanju in Vrba pri Dobrni), iz česar lahko sklepamo, da so bili ti kraji vključeni v širše zaledje provincialnih mest Celeje, Petovione in Nevioduna. Na skrajnem zahodu Slovenije, na robu naselbine Grad pri Reki, je bilo odkrito in raziskano grobišče s I 49 grobovi. Med temi se je nahajal tudi vojaški nagrobnik vojaka petnajste legije (št. I2O), datiran med l. 53 in 31 pr. n. št. Opaziti je mogoče tudi pričakovane razlike med mesti, ki so vidne že v številu vojaških napisov.

\section{Literatura}

Cassius Dio. Rhomaike Historiae. Translated by Earnest Cary. Cambridge, Meassachusests: Harvard University Press, 1927, http://penelope.uchicago.edu/Thayer/E/Roman/ Texts/Cassius_Dio/home.html (23. januar 2014).

Ciglenečki, Slavko. ',Strukturiranost poznorimske poselitve Slovenije = Strukturierung spätantiker Besiedlung Sloweniens“, Arbeološki vestnik 48 (1997): 191-202.

Gaspari, Andrej. »Apud horridas gentis ...« začetki rimskega mesta Colonia Iulia Emona $=$ beginnings of the Roman town of Colonia Iulia Emona. Ljubljana: muzej in galerije mesta Ljubljane, 2010.

Gilliver, Kate. 'The Augustan Reform and Structure of the Imperial Army." In $A$ Companion to the Roman Army, ur. Paul Erd- 
kamp, I83-200. Chichester: Willy-Blackwell, 2007.

Horvat, Jana. ,'Roman Provincial Archaeology in Slovenia Following the Year 1965: Settlement and Small Finds", Arheoloski vestnik 50 (1999): 215-257.

Jevremov, Blagoj. Vodnik po lapidariju. Ptuj: Pokrajinski muzej, 1988.

Lazar, Irena. ,Celeia.“'In Situla, Volume 4o: The autonomous towns of Noricum and Pannonia / Die autonomen Städte in Noricum und Pannonien, vol. I: Noricum, ur. Marjeta Šašel Kos, Peter Scherrer, 7I-Ior. Ljubljana: Narodni muzej Slovenije, 2002.

Lovenjak, Milan. Situla, Volume 37: Neviodunum - Inscriptiones Latinae Slovenia (ILSL) I. Ljubljana: Narodni muzej Slovenije, 1998.

Mikl Curk, Iva, Ciglenečki, Slavko, Vuga, Davorin. Po poteh rimskih vojakov $v$ Sloveniji. Ljubljana: Zavod Republike Slovenije za varstvo naravne in kulturne dediščine Slovenije, 1993.

Saria, Balduin., Vojaški nagrobni napis iz Emone." Kronika slovenskih mest 3, no. I (1937): 46-48.

Svoljšak, Drago and Žbona-Trkman, Beatrice. 1986. 'Novi napisi v Posočju.“ Arheološki vestnik $37,385-398$.

Šašel, Jaroslav. ,'Avgust 69: vojaški puč v Poetovioni." Kronika I, no. 27 (1979): I-7.

Šašel, Jaroslav. 'Dolihenov tempelj, zgrajen v Pretoriju Latobicorum leta 196." Kronika I, no. 30 (1982): 191-193.

Šašel, Jaroslav. ',Zur Frühgeschichte der XV. Legion und zur Nordostgrenze der Cisalpina zur Zeit Caesars“, Situla, Volume 3o: Opera selecta (1992): 469-477.

Šašel, Jaroslav. 'Pro Legato“. Situla, Volume 30 : Opera selecta (I992): 305-315.

Šašel Kos, Marjeta. Zgodovinska podoba prostora med Akvilejo, Jadranom in Sirmijem pri Kasiju Dionu in Herodijanu. Ljubljana, Slovenska akademija znanosti in umetnosti, 1986.
Šašel Kos, Marjeta. 'The isth Legion at Emona - Some thoughts." Zeitschrift für Papyrologie und Epigrafik 109 (1995): 227-244.

Šašel Kos, Marjeta. 'Je bila Emona nekdanji tabor I5. legije in veteranska kolonija?" $Z g o-$ dovinski ćasopis 52, no. 3 (112) (1998): 317329.

Šašel Kos, Marjeta. 'Cestni postaji Atrans in Pretorij Latobikov" In Zakladi tisočletij Zgodovina Slovenije od neandertalcev do Slovanov, ur. Bronislava Aubelj, 238-240. Ljubljana: založba Modrijan, 1999.

Šašel Kos, Marjeta. Lapidarij Narodnega muzeja Slovenije - Rimski spomeniki - Vodnik. Ljubljana: Narodni muzej Slovenije, 2004.

Šašel Kos, Marjeta. Situla, Volume 43: Appian and Illyricum. Ljubljana: Narodni muzej Slovenije, 2005.

Šašel Kos, Marjeta. Rimsko osvajanje zahodnega Balkana: Ilirik v Apijanovi Ilirski zgodovini. Ljubljana: Zveza zgodovinskih društev Slovenije, 2010.

Šašel Kos, Marjeta. 20I2. ,Colonia Iulia Emona - the genesis of the Roman city," Arheološki vestnik 63 (2012): 79-104.

Tacitus. Annales - Ab excessu divi Augusti. Translated By Fran Bradač. Maribor: založba Obzorja, 1968.

Visočnik, Julijana. 2008. ,Vojaški napisi iz Celeje in njene okolice." Arheološki vestnik 59 (2008): 325-357. 